OnLine Journal of Earth Sciences 12 (2-6): 8-29, 2018

ISSN: 1991-7708

(C) Medwell Journals, 2018

\title{
Use of Two Dimensional Electrical Resistivity Imaging to Assess Groundwater Potential in the Basement Rock of Gbongudu Community, Southwestern Nigeria
}

\author{
${ }^{1}$ M.A. Oladunjoye, ${ }^{1}$ A. Adefehinti and ${ }^{2}$ I.A. Korode \\ ${ }^{1}$ Department of Geology, University of Ibadan, Ibadan, Nigeria \\ ${ }^{2}$ Petroleum Training Institute, Petroleum Engineering and Geoscience Department, Effurun, Nigeria
}

\begin{abstract}
Geological structures in crystalline basement rocks have great influence on the groundwater occurrence. If the structures are not mapped with precision, groundwater exploitation may end up being a low yield or dry holes. To assess the groundwater potential of Gbongudu community in Ibadan Southwestern Nigeria, 2-D electrical resistivity imaging and 1-D vertical electrical soundings were utilized. Wenner and Schlumberger configuration techniques were adopted for the acquisition of 2-D resistivity imaging and vertical electrical soundings, respectively. Eleven Electrical Resistivity Imaging (ERI) lines with varying lengths from 100-200 $\mathrm{m}$ and nine vertical electrical soundings. The 2-D field data were inverted using DIPROFWin Software while the 1-D data were plotted on a bi-log graph and interpreted using partial curve matching with suitable auxiliary charts and the result was iterated using "RESIST" Software. Three lithologic units were observed from the 2-D section which are the top layer (reworked clayey soil/compacted lateritic soil), the weathered basement (gravelling sandy-clay/clayey-sand) and the fractured/fresh basement rock while the VES revealed two to three geoelectric layers namely, topsoil, weathered layer, fractured unit and fresh basement. The weathered and the fractured basement form the aquiferous zones in the area investigated. Results of the 2-D ERI shows it is more effective in mapping weathered layer and localized fractures while the VES proved to be effective in detecting overburden thickness, basement fractures and basement topography within crystalline rocks. It was observed that groundwater occurrence within the study area is highly localized and requires detailed investigation to locate productive zones for groundwater development. Prospect areas were limited to areas with relatively thick overburden and fracture basement.
\end{abstract}

Key words: Groundwater potential, Gbongudu community, electrical resistivity imaging vertical electrical sounding, fractured/fresh basement, prospect areas, relatively thick

\section{INTRODUCTION}

Water is very important to man because it is one of the basic components of human existence and socio-economic development but its availability is usually taken for granted in the third world countries. Water supply in Gbongudu community in Ibadan is scarce and the resident of the community rely basically on rain water and from adjoining community for water supply. The short supply of water has limited the development and urbanization of the community. In this community, groundwater which needs little or no purification is considered as an alternative source of water supply to surface water. This study centers on groundwater features of the study area which lies on part of the crystalline rocks of southwestern Nigeria.

Detailed structural geology and hydrogeology of Gbongudu community is not fully known, consequently the yield of the boreholes drilled within this area in the past has been poor there by making groundwater exploitation difficult. The difficulties encountered during exploration for groundwater resources in the study area was as result of complexity of crystalline rocks underlying the study area thus causing the dwindling of the socio-economic activities of the residents. In complex geologic locations like this, groundwater occurrence in relation to geology and geological structures existing within the rocks has to be known.

To locate promising groundwater zones in complex basement terrain is a difficult task and very challenging especially when it is associated with fractured, faulted, jointed and brecciated structures. Al-Garni (2009) observed that the availability of groundwater in this area depends solely on weathered layer thickness overlying the fresh crystalline rocks or fractured basement. The overburden layer which weathers from the basement

Corresponding Author: A. Adefehinti, Department of Geology, University of Ibadan, Ibadan, Nigeria 
contain substantial amount of water because of its high porosity and likewise, the relatively high clay content within it contributes to its low permeability (Barker, 2001). Primarily, the sources of water storage and movement in basement terrain is fractures (Sharma and Baranwal, 2005). The amount of water that can be extracted from basement terrain depend on numbers of factors which are fracture location and size, fractures interconnectivities, the amount of particles that clog the fractures and source (s) of fractures recharge. Fractures in a geologic medium can increase the hydraulic conductivity of impermeable rocks greatly in the direction of the dominant fractures. Louis et al. (2002) observed that the presence of fractures, its extent, its intensity and the fractures direction play significant role in hydraulic engineering project.

In Earth Sciences, geophysical methods are very useful in exploration because they are rapid, cover large hectares in limited time and can also penetrate subsurface to greater depths. Consequently, geophysical exploration techniques have been extensively used in mapping and delineating subsurface structures, monitoring hydro-geologic processes, estimating aquifer parameters, monitoring pollution in subsurface and monitoring geo-hazard events (Hubbard and Rubin, 2006). It has also found usefulness in delineating salt/freshwater boundary (Hodlur et al., 2006, 2010) fresh/weathered layer interface, fracture patterns, joints and faults and monitoring groundwater quality and pollution (Griffths and Barker, 1993; Sharma and Baranwal, 2005). The most used geophysical method in delineating aquifer composition, groundwater method potentials, fresh basement and salt or freshwater interface is electrical resistivity method (Robinson and Coruh, 1988; Burger, 1992; Telford et al., 1990).

Gbongudu Estate in Ibadan located within the basement complex of Southwestern Nigeria is underlain by undifferentiated gneiss which is seen as outcrops in part of the study area. Groundwater exploration and exploitation within this community requires detailed geophysical assessment as a result of erratic nature of the groundwater availability which is evident in many unsuccessful boreholes drilled. The inadequacies in mapping regions of complex geology by one dimensional model of electrical resistivity sounding and profiling, coupled with the assumption of horizontally stratified earth model in resistivity sounding interpretation which fail to reveal the real geologic model and the limitation to map vertical changes in resistivity with depth by profiling method are major drawbacks of these techniques (Griffiths and Bakers, 1993). To assess the presence of groundwater in Gbongudu community, two Dimensional (2-D) Electrical Resistivity Imaging (ERI) and 1-D Vertical
Electrical Soundings (VES) were carried out. A more realistic result was achieved with integration of VES and ERI which offer more detailed model of subsurface. The VES was engaged to achieve resistivity variation with depth at a given point, assuming that laterally the resistivity distribution does not varies. The lithologic layers are delineated using variation in subsurface resistivity achieved from the VES results which frequently produce inaccurate and distorted geologic models in complex geologic area (Pous et al., 1996). In ERI, the lateral and vertical resistivity changes along the survey line are achieved as a continuous mapping of the subsurface even in the region of complex geology and topography (Loke, 2000). Shallow investigation of subsurface has been achieved at different environments through the use of 2-D electrical resistivity tomography (Yang et al., 2002; Hauck et al., 2003; Crook et al., 2008). Zhou et al. (2004), Hsu et al. (2010) and Rao et al. (2013) have shown in their respective studies the usefulness of 2-D electrical resistivity imaging in mapping bedrocks, mineral exploration and groundwater investigation.

This research was carried out to map the subsurface resistivity for borehole development and to select area with groundwater potentials in order to properly manage it. This was achieved by using 2-D electrical resistivity tomography techniques along eleven survey lines which were evenly distributed across the study area and nine vertical electrical soundings which were carried out on ERT line. The 2-D electrical resistivity tomography only covers $25 \mathrm{~m}$ as depth of investigation which in some places is within the regolith or just a little into the basement, the vertical electrical soundings was performed to obtain deeper information along the traverse line. Also, the VES were carried out on the ERT lines in order to confirm the lithologies delineated on it.

Site description and geologic setting: Gbongudu Estate (Fig. 1) is situated in Ibadan, Oyo State, Nigeria and lies

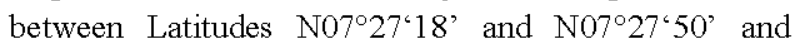
Longitudes E03 $57^{\circ} 45^{\prime}$ and E03 $58^{\circ} 22^{\prime}$. The topography of the area slopes gently with elevation ranging from 210-265 $\mathrm{m}$ above mean sea level. The location is found in tropical rain forest belt of Nigeria which is characterized by wet and dry seasons. The wet season is lengthy and runs from March-October while the dry season being shorter runs from November-February. Based on NIMET (2011) report that the study location has mean annual rainfall of is $1420.06 \mathrm{~mm}$ while the mean annual temperature is $26.46^{\circ} \mathrm{C}$ and relative humidity is $74.55 \%$. 


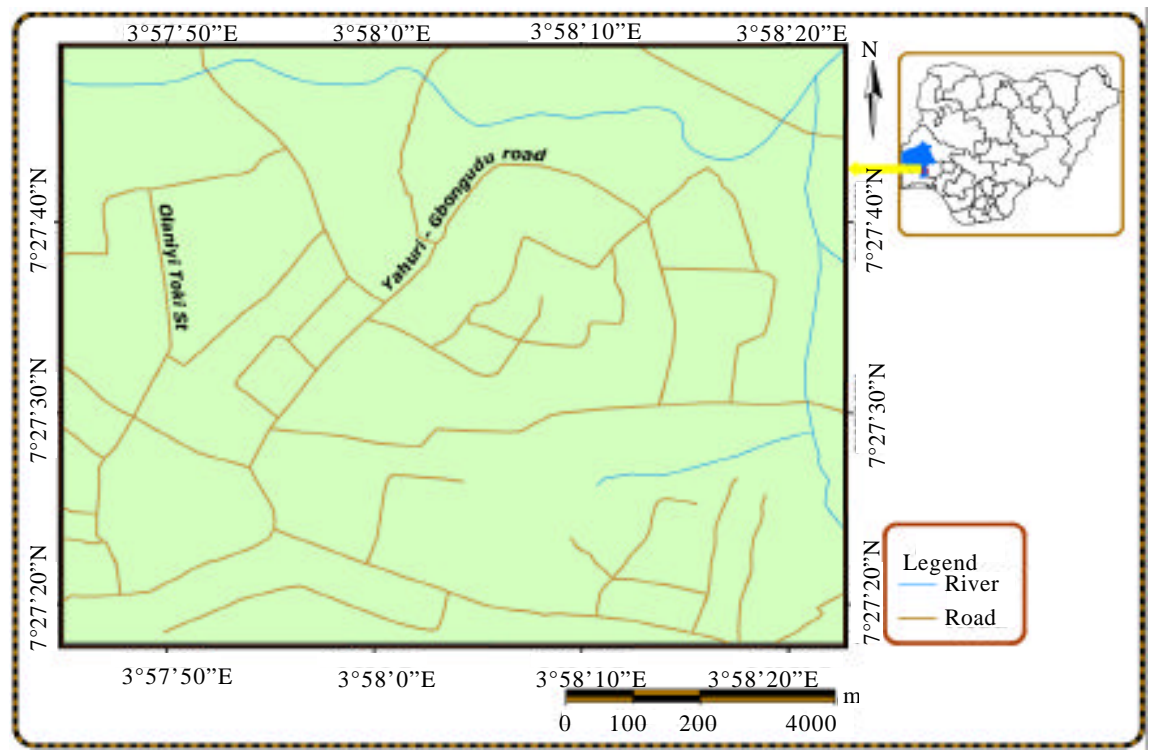

Fig. 1: Map of the study area showing the location and drainage

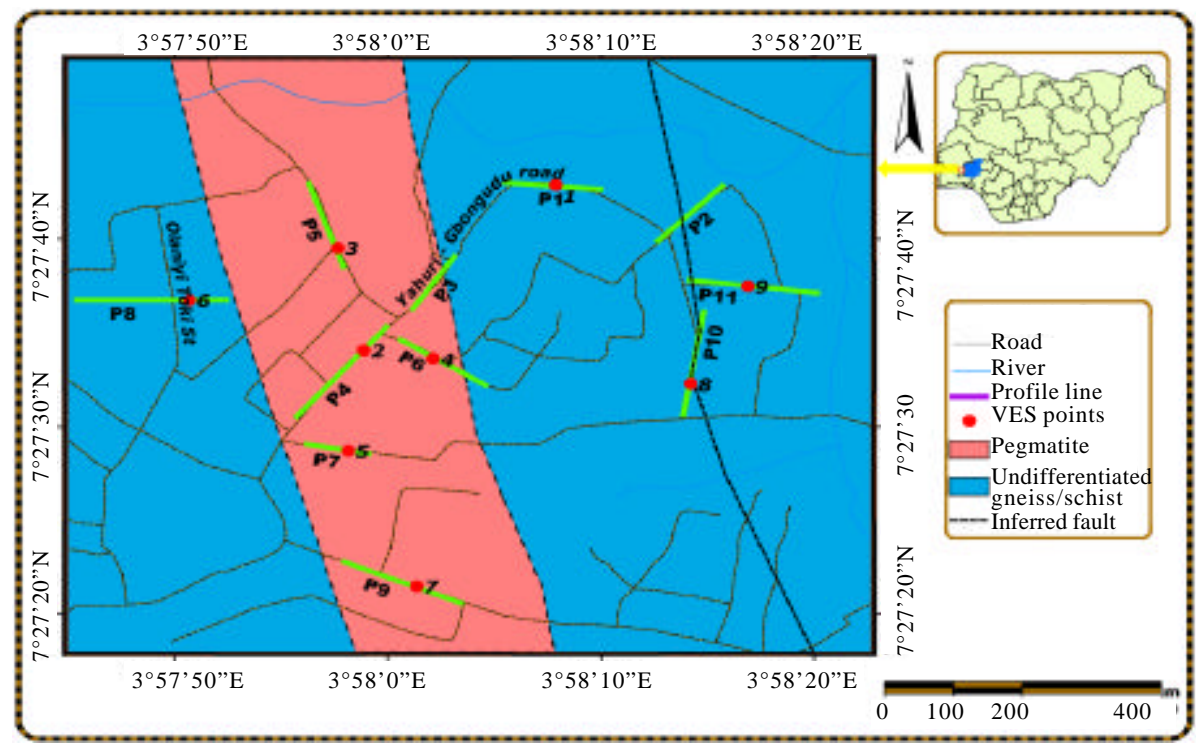

Fig. 2: Geological map of Gbongudes community (Nigeria Geological Survey Agency (NGSA), 2009)

The study area in Fig. 2 is covered by Precambrian crystalline rocks of southwestern Nigeria which is part of Nigeria basement complex (Oyinloye, 2011). Outcrop observation and literature review revealed that the area is underlain by migmatite gneiss. The migmatite gneiss was intruded by pegmatite vein in the middle part of the host rock. The host rock strike in NW-SE direction and a careful examination revealed that the major fracture direction is perpendicular to the general strike direction of the main rock (NIMET, 2011).

\section{MATERIALS AND METHODS}

1-D sounding technique is greatly limited because horizontal changes in the subsurface resistivity are not considered while it still provides variation in subsurface resistivity vertically. Two-Dimensional (2-D) model gives more accurate information of the subsurface in that it takes into account changes in resistivity along vertical and horizontal directions on the survey line. 2-D electrical resistivity imaging was carried out using four electrodes 


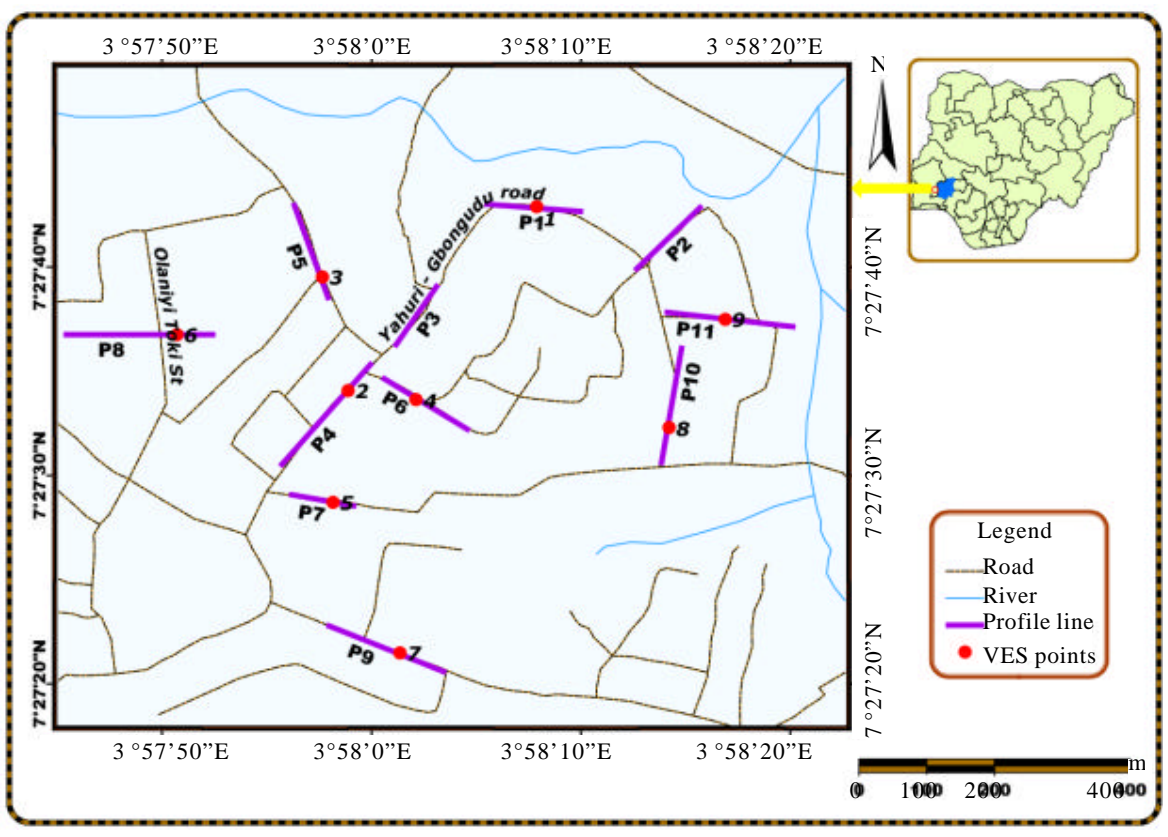

Fig. 3: Location map of Gbongudu community showing profile lines and VES points

which were manually moved along the survey line. For each measurement, the relevant four electrodes are automatically selected on a laptop microcomputer with an electronic switching unit which is connected to multi-core electrode. Manual movement was achieved with set of four electrodes moving along the profile line with the shortest electrode spacing $5 \mathrm{~m}(\mathrm{n}=1)$ and value of apparent resistivity obtained. The current and potential electrodes are shifted successively by one electrode separation along the profile line after obtaining the resistivity value for point. Least electrode spacing is used to obtain data for level and once it was completed, the electrode spacing was doubled $(\mathrm{n}=2)$ and the process repeated until the appropriate number of levels has been achieved. The apparent resistivity values obtained for each measurement was plotted as a pseudosection and contoured.

In this investigation, eleven traverse lines were established and field resistivity data were obtained along each line. Figure 3 shows the profile lines, where profile 10 , profiles $1,7,8$ and 11 , profiles 2,3 and 4 and profiles 5 , 6 and 9 are oriented in North-South, West-East, Northeast Southwest and Northwest Southeast directions respectively. For each profile, Wenner electrode configuration was adopted with least electrode separation of $5 \mathrm{~m}$ and maximum of six levels were achieved for each profile. Certain conditions must be meant by an electrode configuration before it can be considered for any field survey. Wenner array was chosen for this study because of its sensitivity to vertical changes in subsurface resistivity, i.e., good in mapping horizontal structures, moderate depth of investigation and strong signal strength. The field data obtained were processed and inverted by DIPROFWin, a 2-D resistivity data processing software developed by KIGAM which was coded based on 2.5 dimensional finite element and smoothness constrained least-square inversion adopting Active Constraint Balancing method (Yi et al., 2003). The inversion was carried out until a reasonable fit was obtained by minimizing the difference in initial synthetic model of subsurface resistivity distribution and the observed resistivity fields.

Schlumberger array was adopted in carrying out nine VES with current electrode separation $(\mathrm{AB})$ ranging from 110-200 m. The four electrodes were arranged collinearly, while the distance between the potential electrodes were kept constant and at each measurement, the current electrode spacing varied. Campus Tigre resistivity meter was used to acquire both the VES and 2D ERT data with observed error being $<1 \%$. Field data obtained were processed with WinRESIST computer program to determine the geoelectric model parameters for delineated layers. The field curves were initially matched on bi-log graph sheets with appropriate theoretical curves. 


\section{RESULTS AND DISCUSSION}

Vertical electrical soundings (VES): The geoelectric parameters obtained from the VES results were used to delineate subsurface into two or three geoelectric layers which include topsoil which is lateritic in some places, weathered layer (clay/sandy clay), fractured unit and fresh basement. Table 1 shows the summary of the VES interpretation carried out at the study area. The layers delineated from the geoelctric parameters are; topsoil (lateritic/clayey soil) which has resistivity value ranging from $79-521 \Omega \mathrm{m}$ with average resistivity of $230 \Omega \mathrm{m}$ and has thickness ranging from 0.8-6.8 $\mathrm{m}$ with average thickness of $2.1 \mathrm{~m}$, the weathered layer (clay/sandy clay) has resistivity ranging from 27-137 $\Omega \mathrm{m}$ with average resistivity of $79 \Omega \mathrm{m}$ and has thickness ranging from $1.9-11.5 \mathrm{~m}$ with average thickness of $5.6 \mathrm{~m}$ and the fracture unit/fresh basement has resistivity ranging from 257-6958 $\Omega \mathrm{m}$ with average resistivity of $1961 \Omega \mathrm{m}$. The weathered layer may not be able to support groundwater yield because it is generally less than the thickness suggested by Olayinka et al. (2004) and Barker et al. (1992). The basement resistivity is high in most VES locations which indicate very low porosity and negligible permeability. Figures 4-12 show the inverted curves/layer model interpretation and the geoelectric log generated from the geolectric parameters. The logs show the lithology of the subsurface at each VES point which gave a pictorial view for easy and better understanding.

\section{Interpretation of 2-D electrical resistivity tomography:}

The 2-D inverse model results are displayed as sections which permit the identification of variation of true electrical resistivity of the subsurface with depth along the profile. The range of resistivity from relatively low to relatively high zones showed how the potential measured by the array used was being influenced by the degree of change in resistivity of the subsurface on a profile line which is referred to as sensitivity function. High value of sensitivity function implies that higher influence of subsurface region on the measured zone (Loke, 2004). An ambiguity of this nature can be reduced by having additional data coverage. Geological structures such as fracture zones were identified on the 2-D resistivity tomography.

\section{Interpretation of 2-D electrical resistivity tomography:}

The 2-D inverse model results are displayed as sections which permit the identification of variation of true electrical resistivity of the subsurface with depth along the profile. The range of resistivity from relatively low to relatively high zones showed how the potential measured by the array used was being influenced by the degree of change in resistivity of the subsurface on a profile line which is referred to as sensitivity function. High value of sensitivity function implies that higher influence of subsurface region on the measured zone (Loke, 2004). An ambiguity of this nature can be reduced by having additional data coverage. Geological structures such as fracture zones were identified on the 2-D resistivity tomography.

Profile 1: The 2-D electrical imaging for profile1 (Fig. 13) with length of $150 \mathrm{~m}$ was obtained in W-E direction and located in the Northern part of the study area. Three lithologic unit observed on the profile can be referred to as the topsoil which is lateritic, the weathered layer and the fresh basement which could either be fractured or fresh. The upper part of the 2-D inverted model revealed material with resistivity between 100-250 $\Omega \mathrm{m}$ and an average thickness of $4 \mathrm{~m}$ which form the topsoil. The layer can be interpreted from the resistivity as lateritic clay where the resistivity value is high and clayey sand where the resistivity is not too high. The top layer is underlain by a more resistive layer with average thickness of about $7 \mathrm{~m}$ and has resistivity value ranging from $250-700 \Omega \mathrm{m}$. This layer covered the entire profile line but with varying thickness and is found at different depth because of varying degree of weathering profile. The weathered and fresh basement contact is suspected to be either fractured or saturated because it has resistivity lower than that of the fresh basement. The depression found between 65 and $90 \mathrm{~m}$ on the profile which has resistivity value ranging 722 and $1033 \Omega \mathrm{m}$ which is less than that of the fresh basement was interpreted as fractured zone and could be saturated. The base of the profile was occupied by fresh basement with resistivity values greater than $1000 \Omega \mathrm{m}$. The intruding fresh basement found at the base of the profile shows uneven surface of the basement which is as a result of the variation in the degree of resistance to chemical weathering by the underlying rocks along the profile in the subsurface. On this profile, VES1 (Fig. 4) was carried out at $70 \mathrm{~m}$ and three geoelectric layers was revealed which were interpreted based on geoelectric parameters observed as topsoil, weathered layer and fractured unit. This corresponds to what was observed on the 2D ERI inverted model section at $70 \mathrm{~m}$. The VES was used as a complementary tool to the ERT result.

Profile 2: Profile 2 (Fig. 14) was obtained in NE-SW direction and located in the northeastern part of the study area with a length of $120 \mathrm{~m}$. The variation in the resistivity values as seen on the profile is an indicative of anomalous zones. The upper part of the profile which is about $10 \mathrm{~m}$ 
OnLine J. Earth Sci., 12 (2-6): 8-29, 2018

Table 1: Summary of geoelectric parameter of VES curves

\begin{tabular}{|c|c|c|c|c|c|c|c|c|}
\hline \multirow{2}{*}{ VES No. } & \multicolumn{3}{|c|}{ Lay er resistivity $(\Omega m)$} & \multicolumn{2}{|c|}{ Layer thickness (m) } & \multirow{2}{*}{\multicolumn{3}{|c|}{ Probable lithology }} \\
\hline & $\rho_{1}$ & $\rho_{2}$ & $\rho_{3}$ & $\mathrm{~h}_{1}$ & $\mathrm{~h}_{2}$ & & & \\
\hline 1 & 521 & 120 & 598 & 0.8 & 05.1 & Topsoil & Weathered layer & Fractured unit \\
\hline 2 & 82 & 4584 & - & 2.4 & - & Topsoil & Fresh basement & \\
\hline 3 & 396 & 53 & 6958 & 0.8 & 01.9 & Topsoil & Weathered layer & Fresh basement \\
\hline 4 & 396 & 137 & 3231 & 1.8 & 03.8 & Topsoil & Weathered layer & Fresh basement \\
\hline 5 & 308 & 117 & 904 & 0.8 & 03.9 & Topsoil & Weathered layer & Fresh basement \\
\hline 6 & 79 & 66 & 257 & 2.2 & 04.8 & Topsoil & Weathered layer & Fractured unit \\
\hline 7 & 105 & 543 & - & 6.8 & - & Topsoil & Fractured unit & \\
\hline 8 & 91 & 35 & 301 & 2.0 & 11.5 & Topsoil & Weathered layer & Fresh basement \\
\hline 9 & 92 & 27 & 275 & 1.4 & 08.0 & Topsoil & Weathered layer & Fractured unit \\
\hline
\end{tabular}
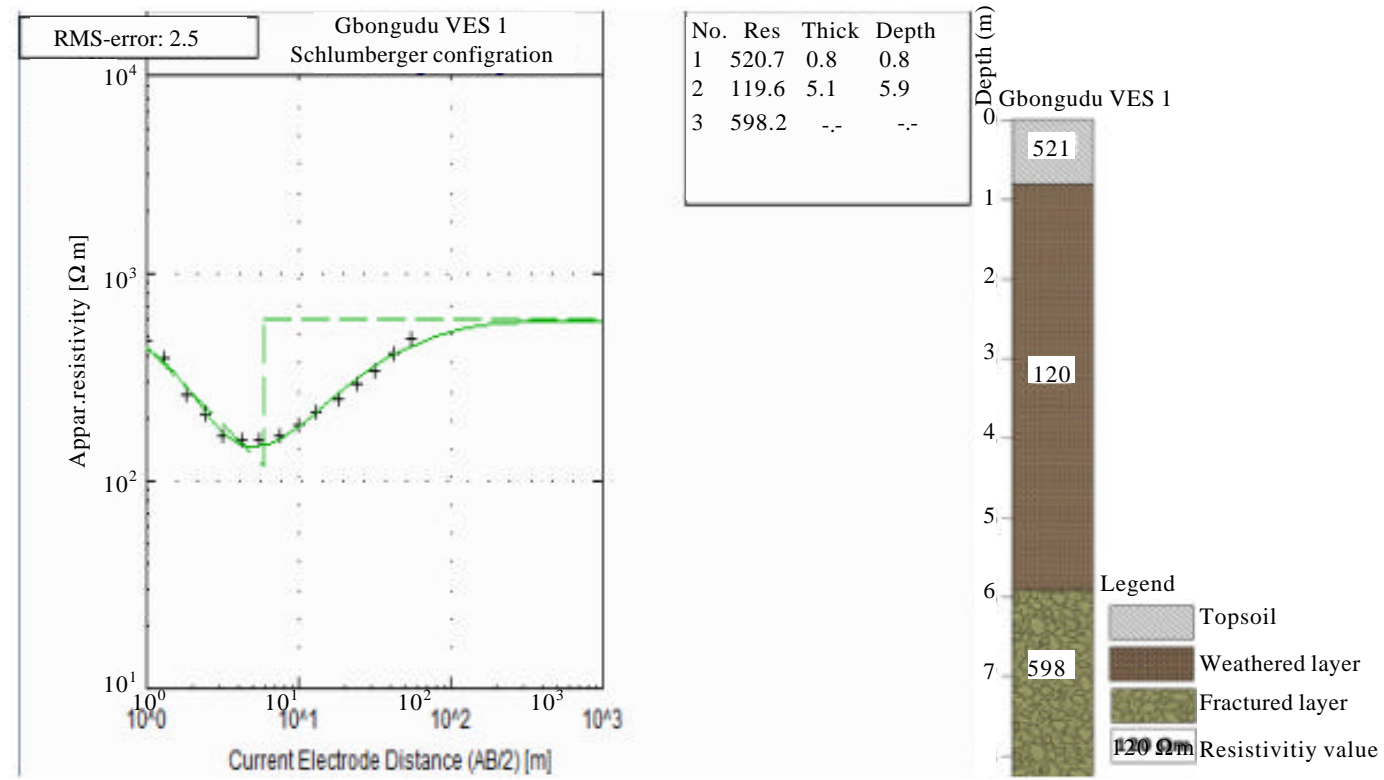

Fig. 4: Interpreted VES curve and geoelectric log for Gbongudu VES 1
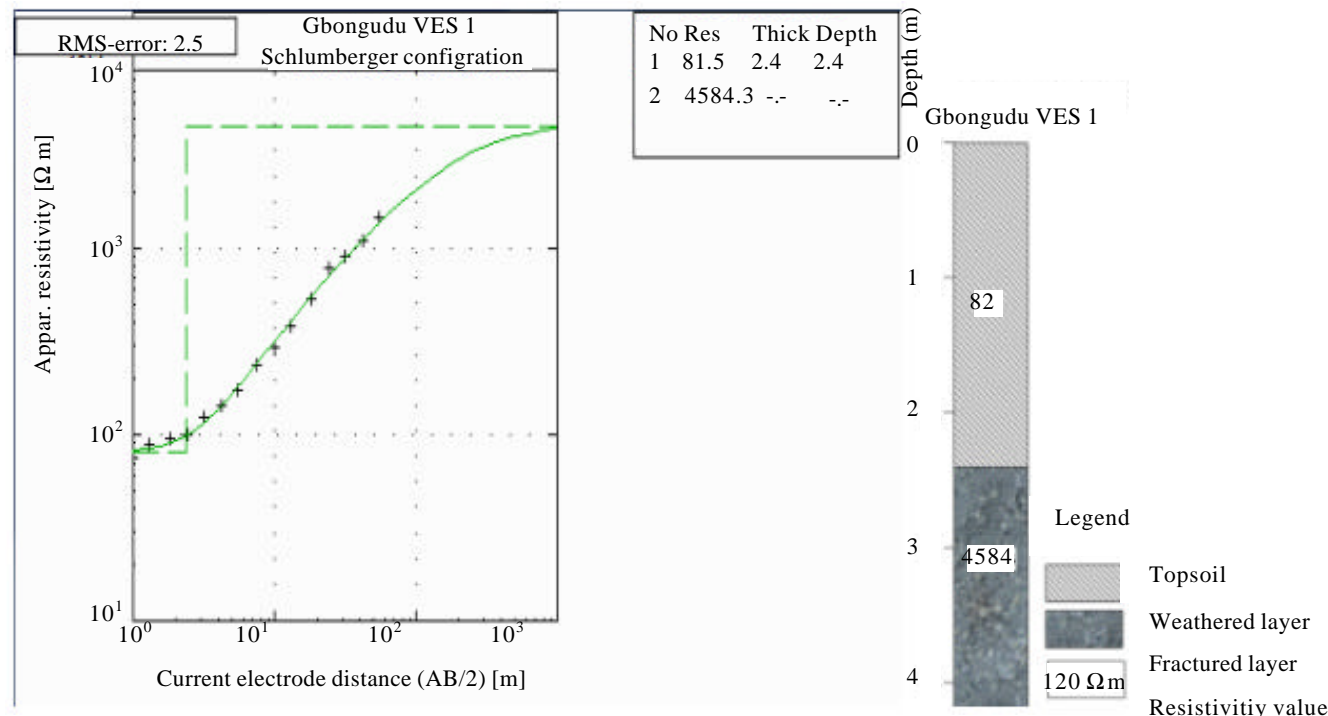

Fig. 5: Interpreted VES curve and geoelectric log for Gbongudu VES 2 


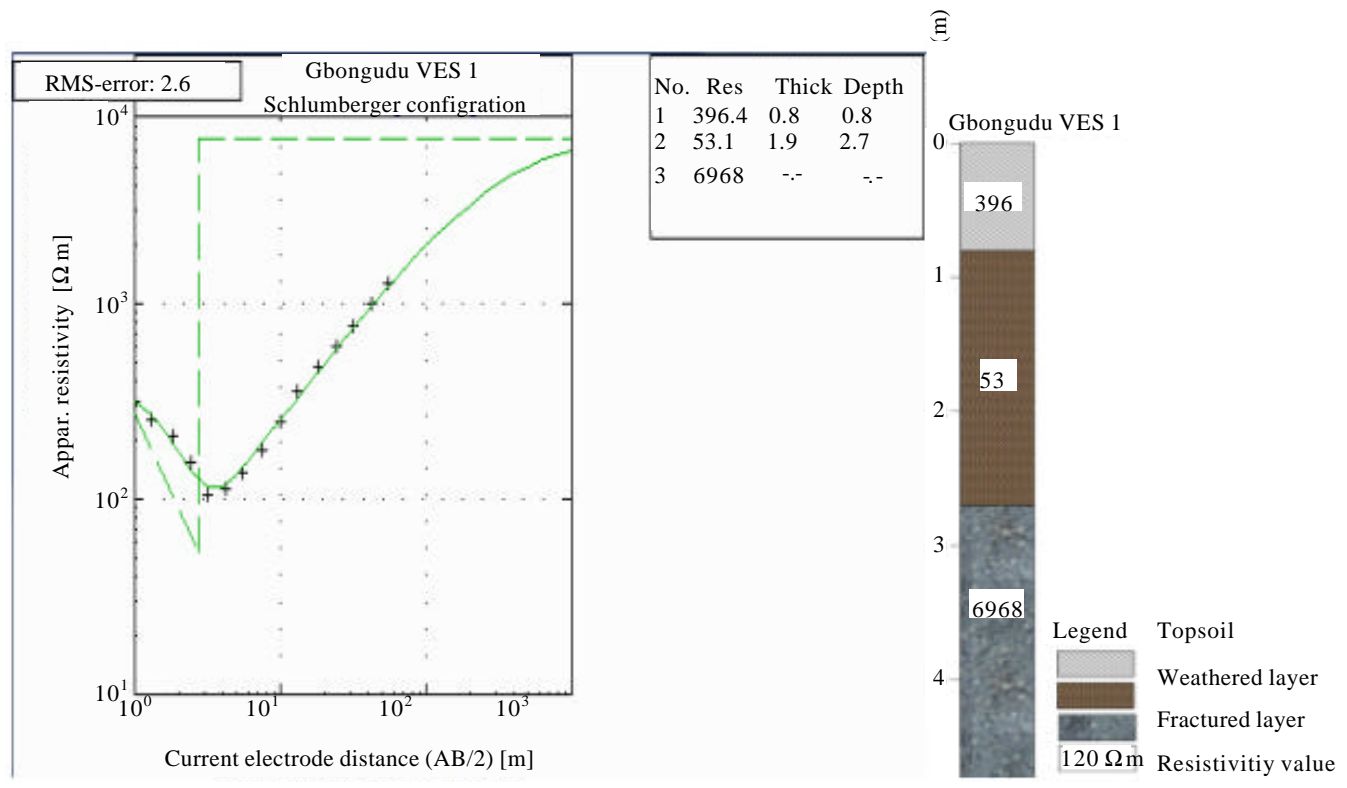

Fig. 6: Interpreted VES curve and geoelectric log for Gbongudu VES 3
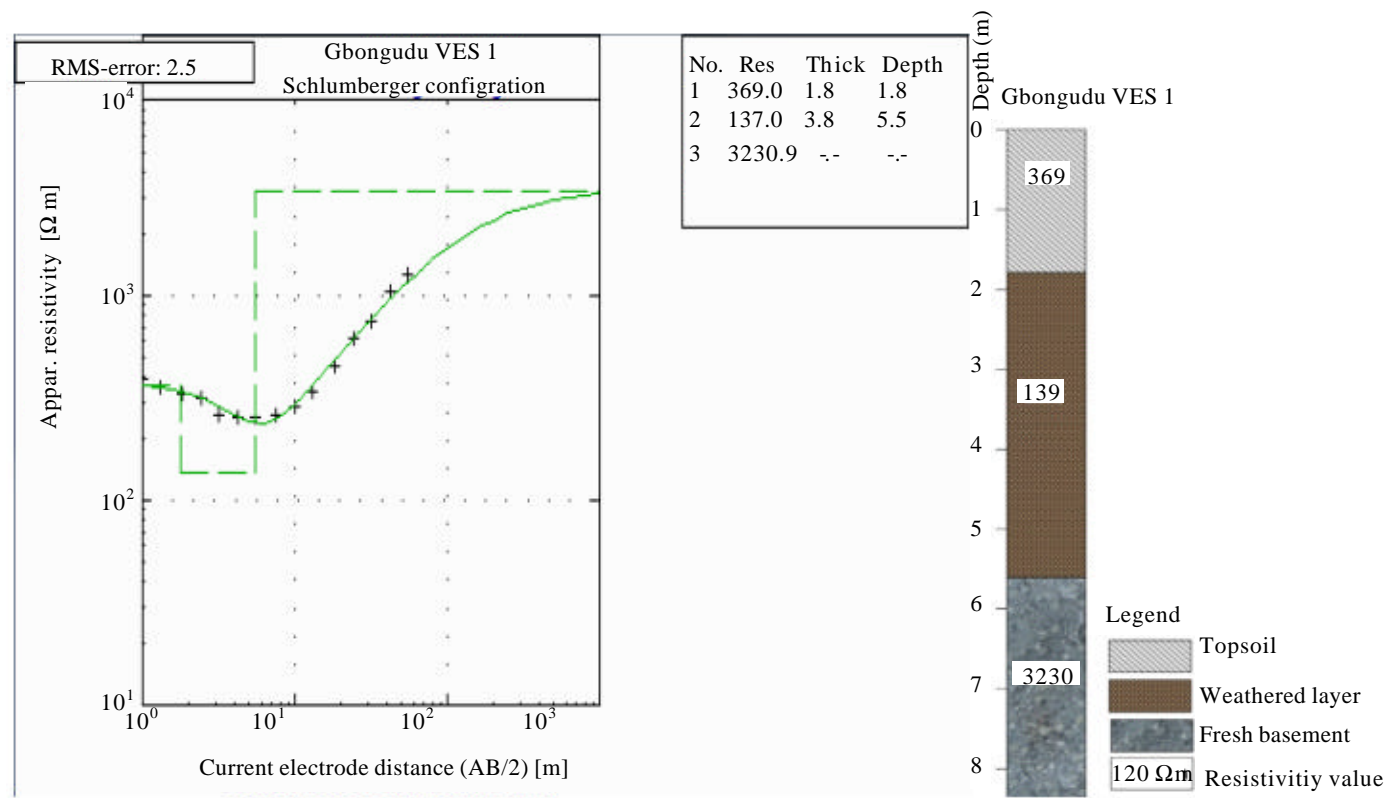

Fig. 7: Interpreted VES curve and geoelectric log for Gbongudu VES 3

thick was occupied by a low resistivity layer which has resistivity values ranging between $100-130 \Omega \mathrm{m}$. This layer was interpreted to be wet sandy-clay and is not too compacted which was responsible for the low resistivity. Underlying the top layer is a layer with resistivity values ranging between 140-250 $\Omega \mathrm{m}$ with average thickness of about $7 \mathrm{~m}$. This layer was interpreted as weathered layer which is composed of clayey-sand. Below this layer is the last layer which has resistivity value higher than $250 \Omega \mathrm{m}$. This layer was interpreted as fractured basement and is likely be saturated which is responsible for the low resistivity. The layers displayed have almost equal thickness along the profile which indicates uniform weathering along the profile line.

Profile 3: Image of the 2-D electrical resistivity imaging for profile 3 is shown in Fig. 15. The profile is located in the central part of the study area and was obtained in Northeast-Southwest direction with total length of $100 \mathrm{~m}$ due to space constraint. The inverted section delineate 
OnLine J. Earth Sci, 12 (2-6): 8-29, 2018

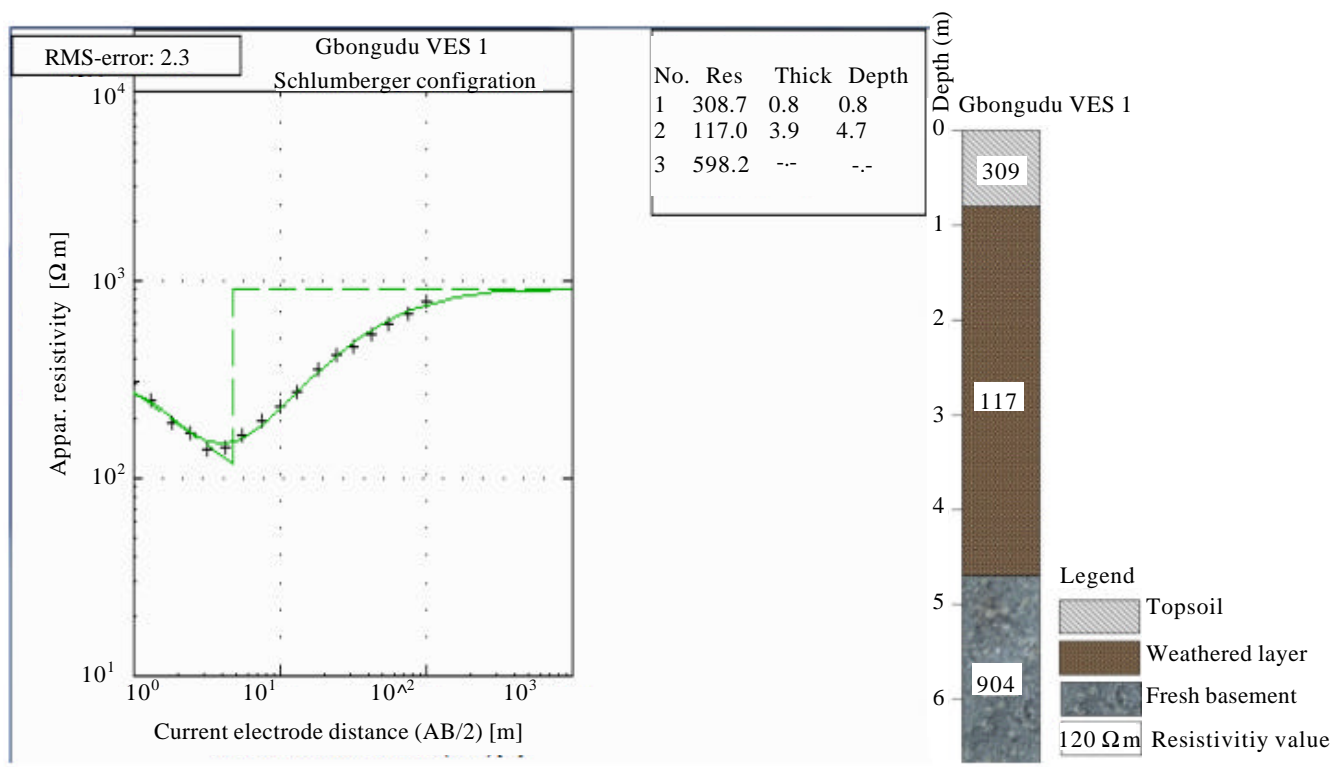

Fig. 8: Interpreted VES curve and geoelectric log for Gbongudu VES 5

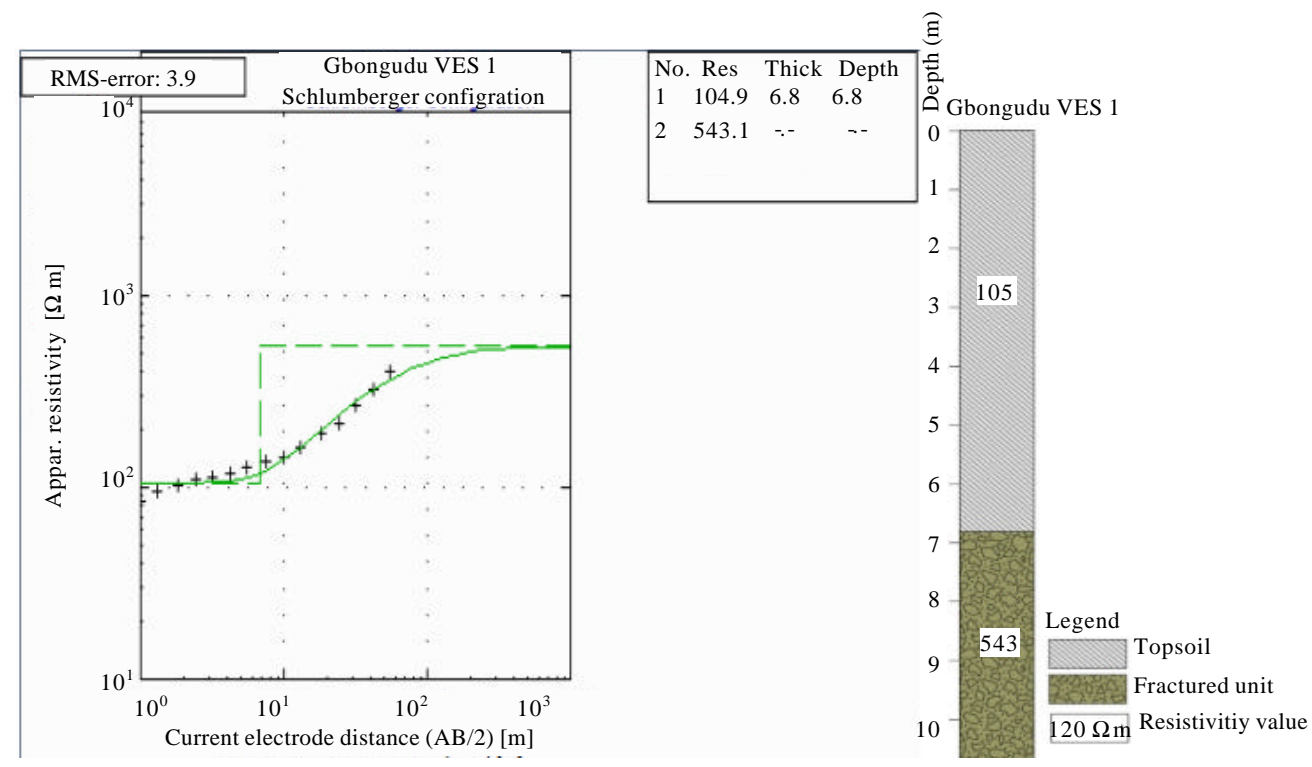

Fig. 9: Interpreted VES curve and geoelectric log for Gbongudu VES 6

three layers which are the topsoil, weathered layer and fresh bedrock. The topsoil has resistivity value ranging from 100-150 $\Omega \mathrm{m}$ with average thickness of about $2 \mathrm{~m}$ which was interpreted to compose of loose but wet soil particles which was responsible for the low resistivity observed on the section. This was underlain by a layer which has resistivity ranges from $200-600 \Omega \mathrm{m}$ with an average thickness of about $3 \mathrm{~m}$. The layer was interpreted to be weathered layer that composed of clayey soil impregnated with gravelling sand. The base of this profile was occupied by fresh basement rock which has resistivity greater than $1000 \Omega \mathrm{m}$. The contact between the weathered layer and fresh basement may either be fractured or saturated. The uneven surface of the basement rock is as a result varying degree of resistant to weathering by the basement rock.

Profile 4: Figure 16 shows the subsurface resistivity as displayed by 2-D electrical resistivity imaging along profile 4 with a total spread length of $200 \mathrm{~m}$. The profile 


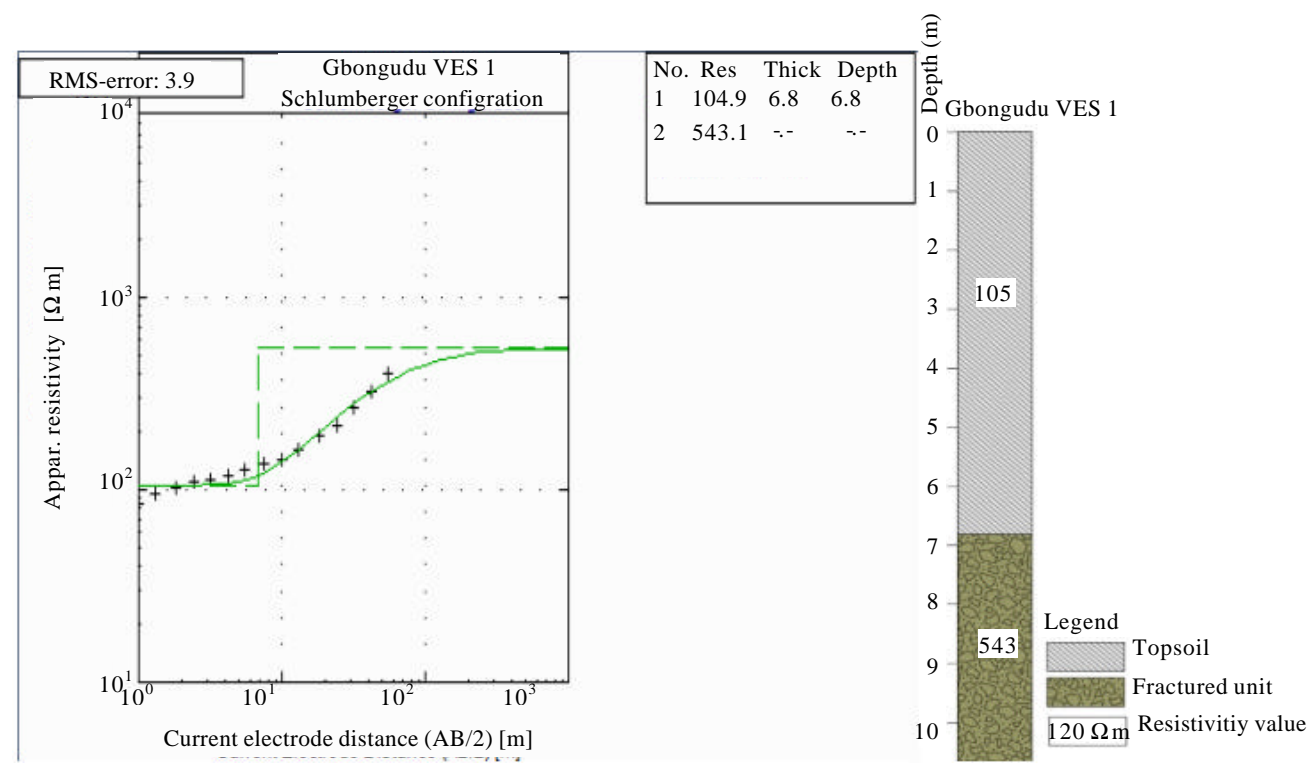

Fig. 10: Interpreted VES curve and geoelectric log for Gbongudu VES 7

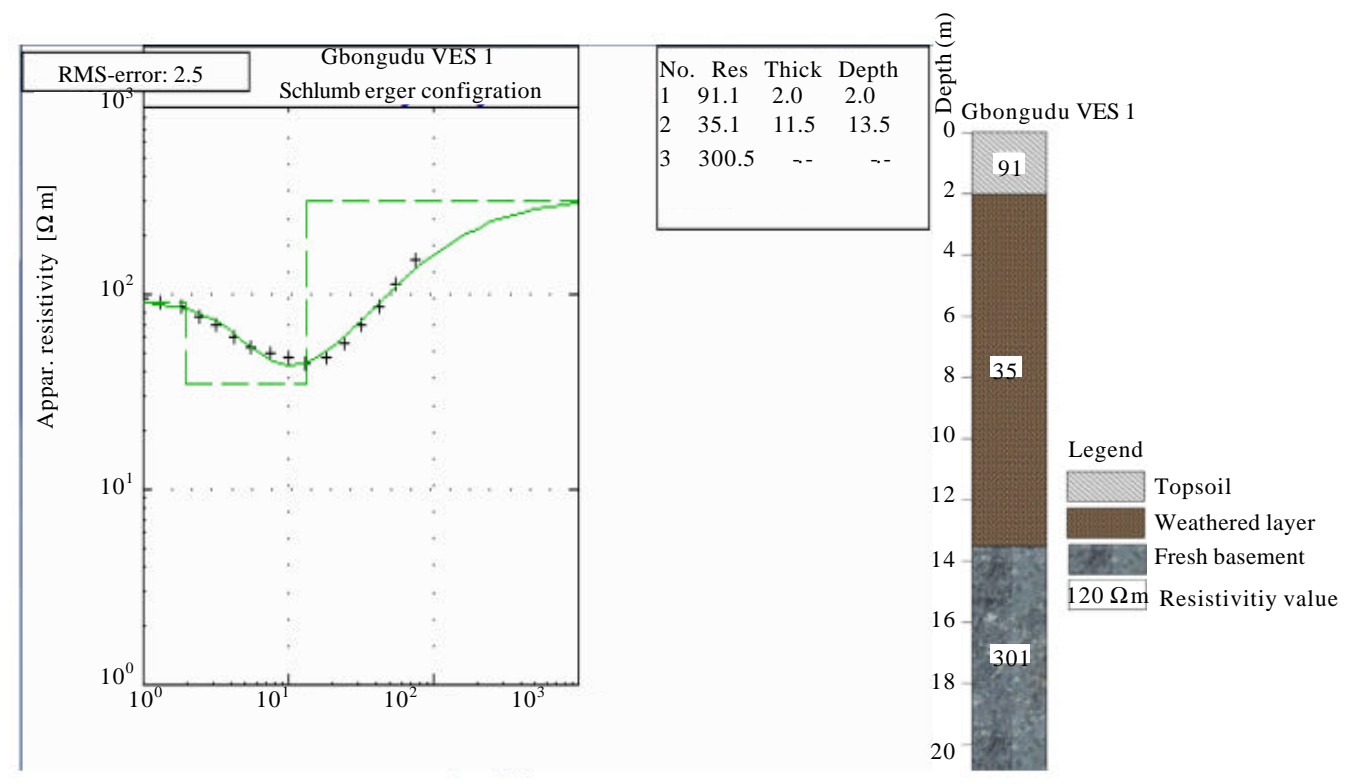

Fig. 11: Interpreted VES curve and geoelectric log for Gbongudu VES 8

was obtained in Northeast-Southwest direction and was located at the central part of the study area. At near surface the topsoil is made of reworked soil of about $3 \mathrm{~m}$ thick with resistivity values ranging between 100-250 $\Omega \mathrm{m}$. The topsoil is getting thicker towards the end of the profile which shows evidence of deeper weathering profile along the section. Underlying the top layer is a moderate resistivity layer with resistivity values ranging between $300-700 \Omega \mathrm{m}$ with an average thickness of about $4 \mathrm{~m}$. This layer was interpreted as the weathered layer and composed mainly clayey sand which has gravel of quartz embedded within it. The weathered layer has uniform thickness across the profile but was encountered at different depth. Occupying the base of the profile was a very high resistivity layer with resistivity of above $1100 \Omega \mathrm{m}$ and was interpreted as fresh basement. The fresh basement is close to the surface from the beginning of the profile to about $170 \mathrm{~m}$ and this shows that the weathering profile is not thick which sometimes make it impossible for the weathered layer to be saturated. The basement has 


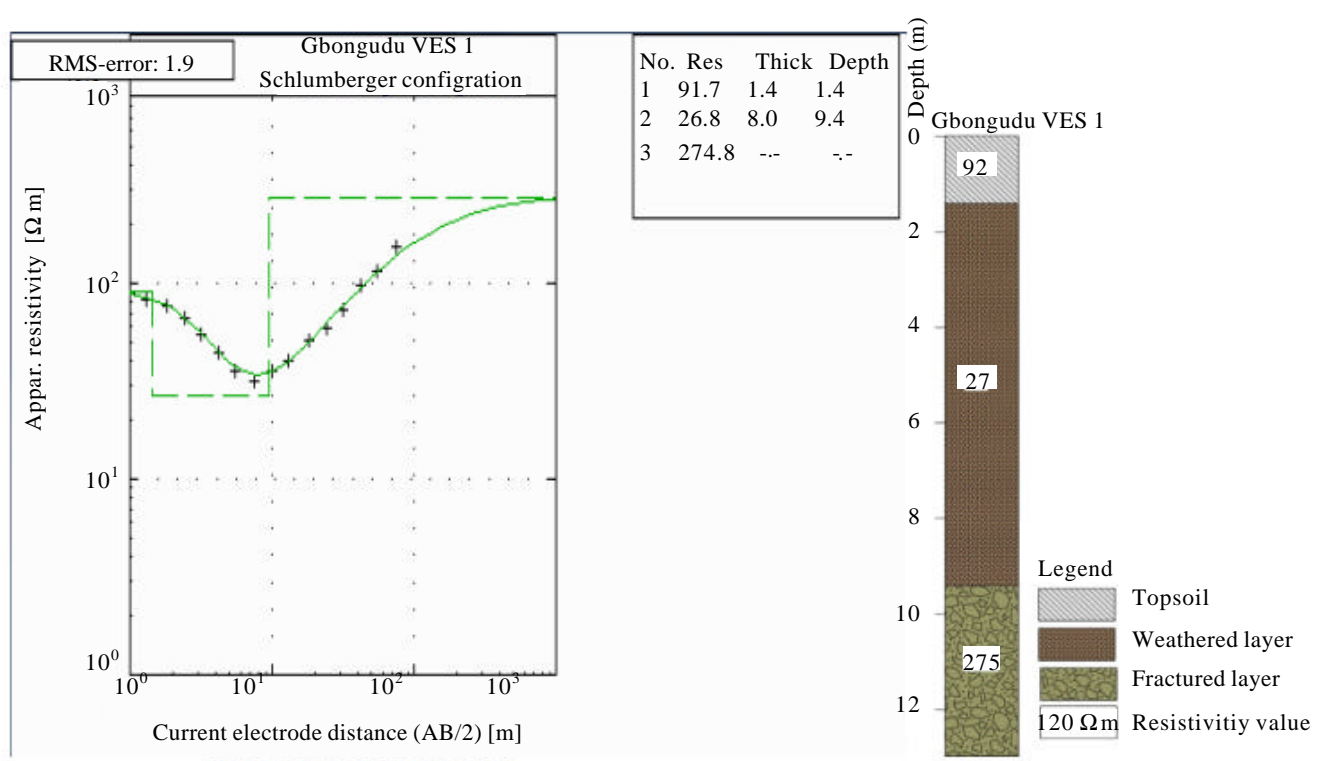

Fig. 12: Interpreted VES curve and geoelectric log for Gbongudu VES 9

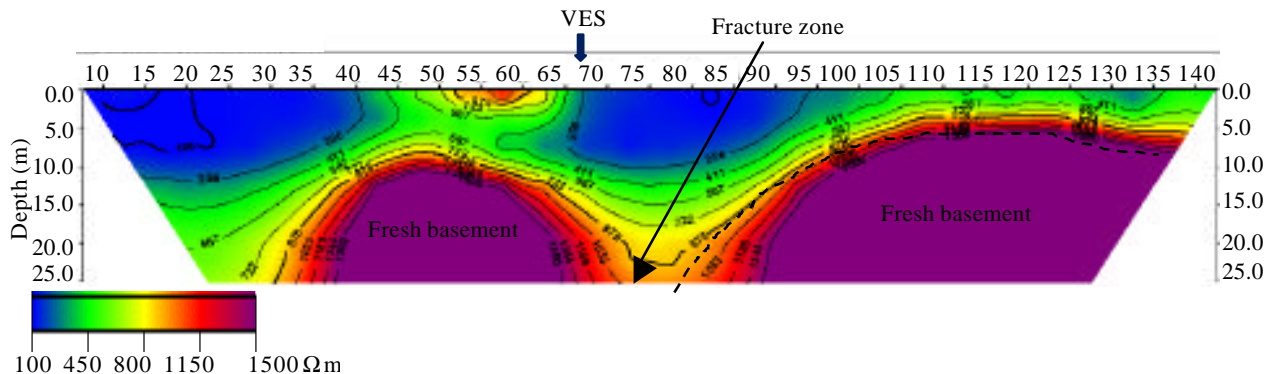

Fig. 13: 2-D Electrical resistivity inverse model section for profile 1

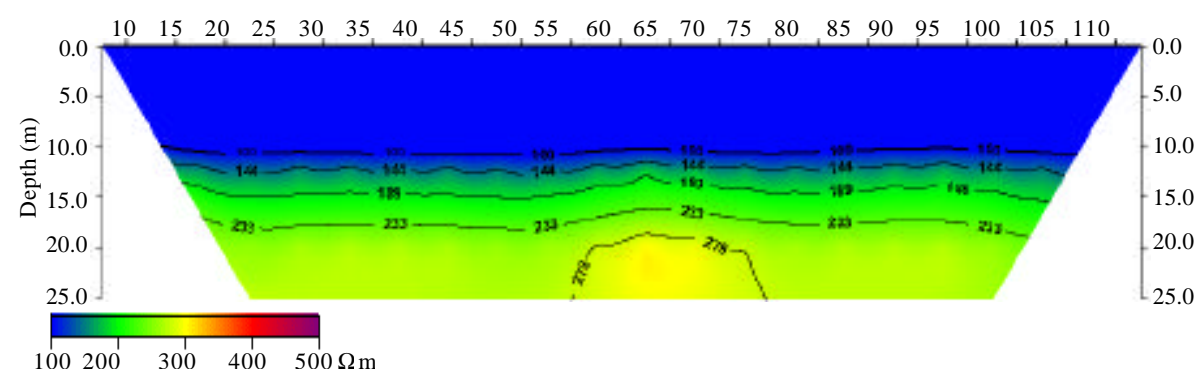

Fig. 14: 2-D Electrical resistivity inverse model section for profile 2

uneven surface which result from the irregular weathering on the basement. The uneven surface of the basement made it difficult for groundwater to accumulate within the weathered basement because it is not thick enough. The depression found at the end of the profile where the fresh basement is not too evident could be as result of fracture within the basement and if fracture, it will serve as groundwater storage center for water that infiltrates from $80 \mathrm{~m}$ on the profile. The VES 2 (Fig. 5) carried out at $53 \mathrm{~m}$ shows topsoil and fresh basement. The topsoil which composed of clayey soil has thickness of about $2.4 \mathrm{~m}$ with resistivity of $82 \Omega \mathrm{m}$. The VES result show evidence of fracturing at the top of the fresh basement and the regolith here is thin.

Profile 5: Figure 17 and 18 shows the subsurface resistivity as displayed by $2-\mathrm{D}$ electrical resistivity imaging along profile 5 with spread length $150 \mathrm{~m}$ and 


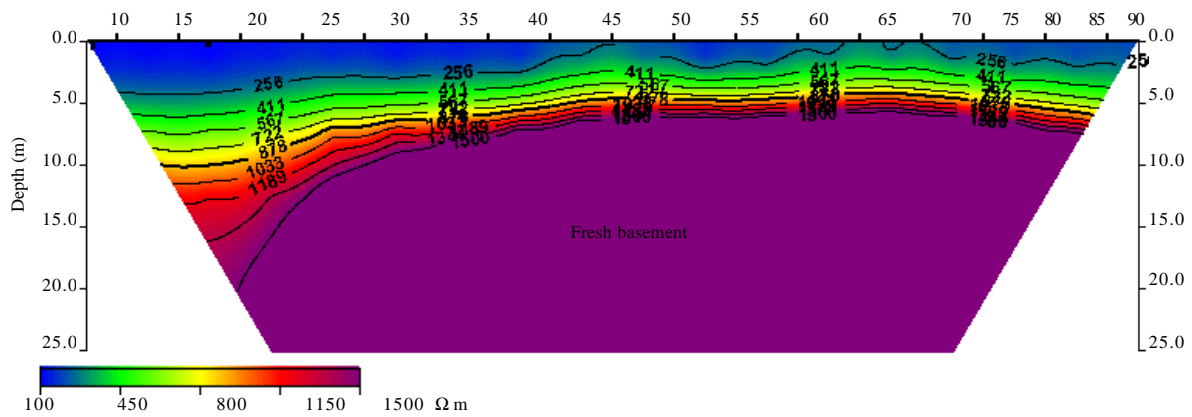

Fig. 15: 2-D Electrical resistivity inverse model section for profile 3

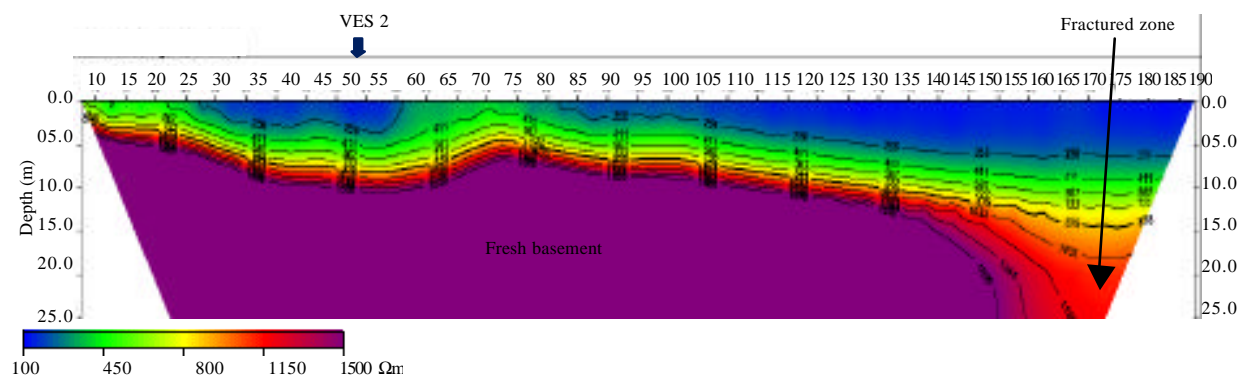

Fig. 16: 2-D Electrical resistivity inverse model section for profile 4

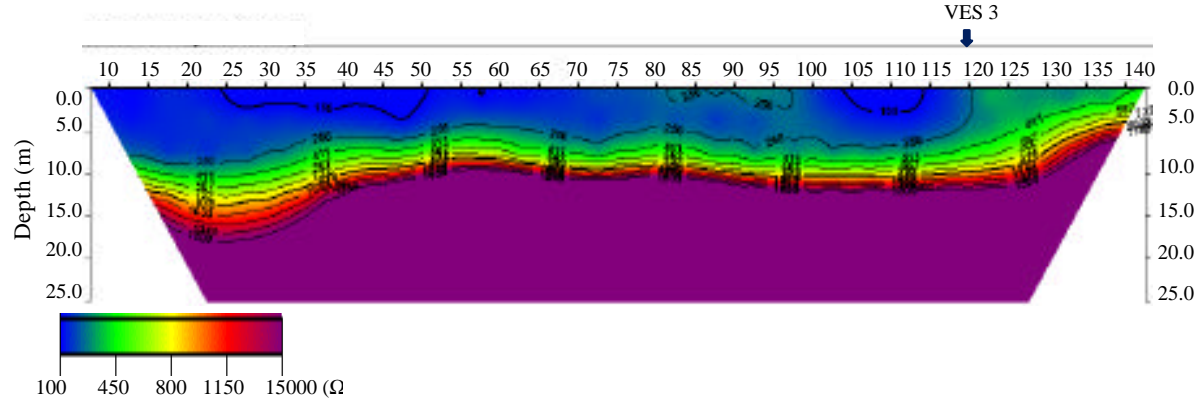

Fig. 17: 2-D Electrical resistivity inverse model section for profile 5

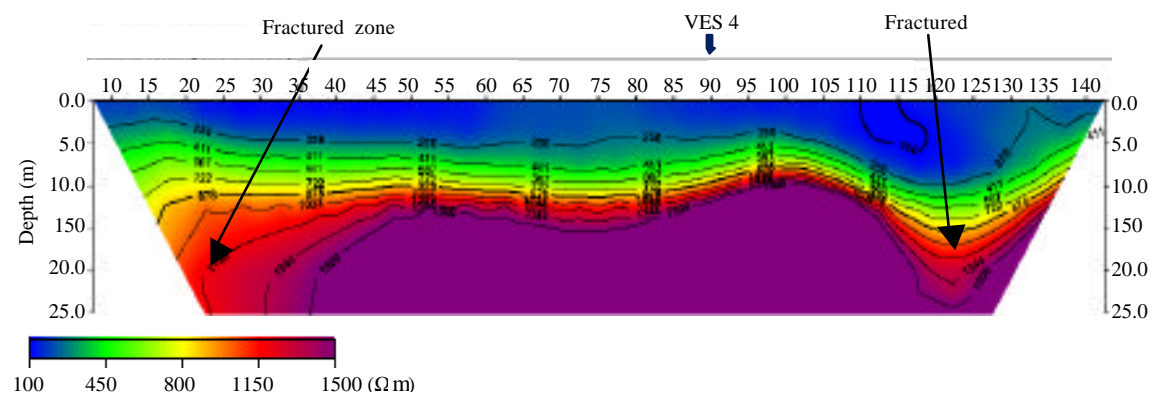

Fig. 18: 2-D Electrica; resistivity inverse model section for profile 6

obtained in Northwest-Southeast direction. Observed at the topmost of the profile is very low resistivity value ranging from $100-300 \Omega \mathrm{m}$ with average thickness of about $4 \mathrm{~m}$. This topmost layer which has uneven base due to different degree of weathering across the profile was interpreted as topsoil that is made of clayey soil. 


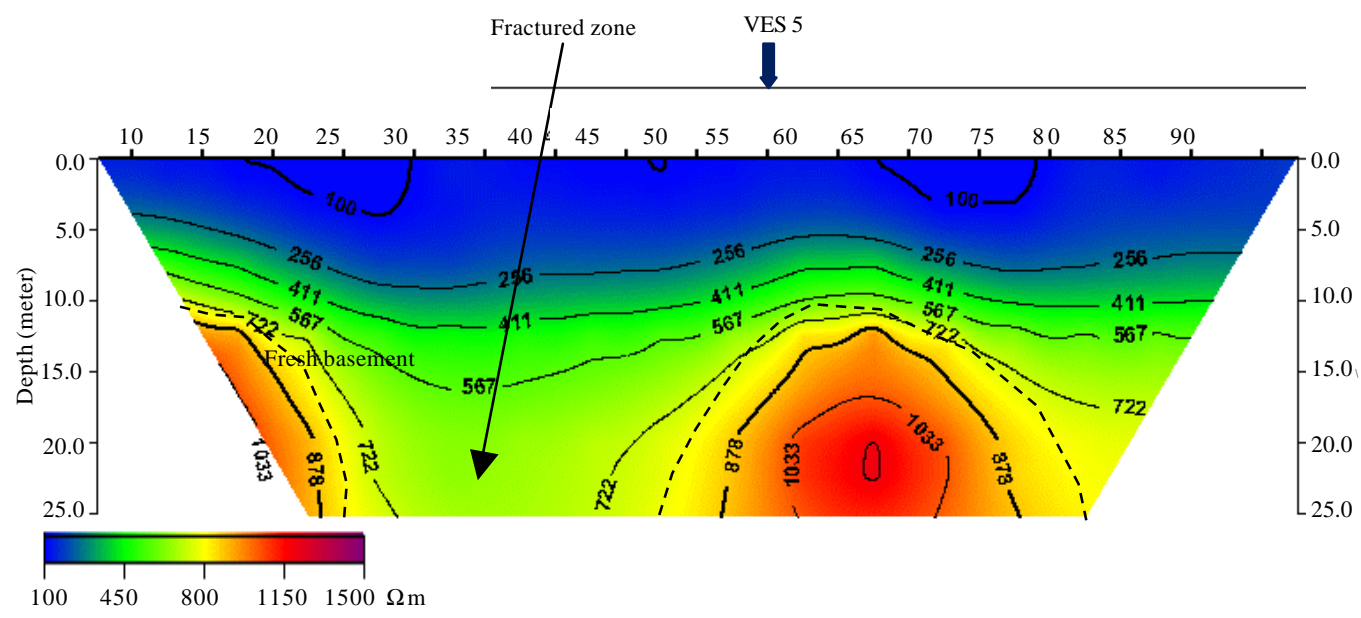

Fig. 19: 2-D Electrica; resistivity inverse model section for profile 7

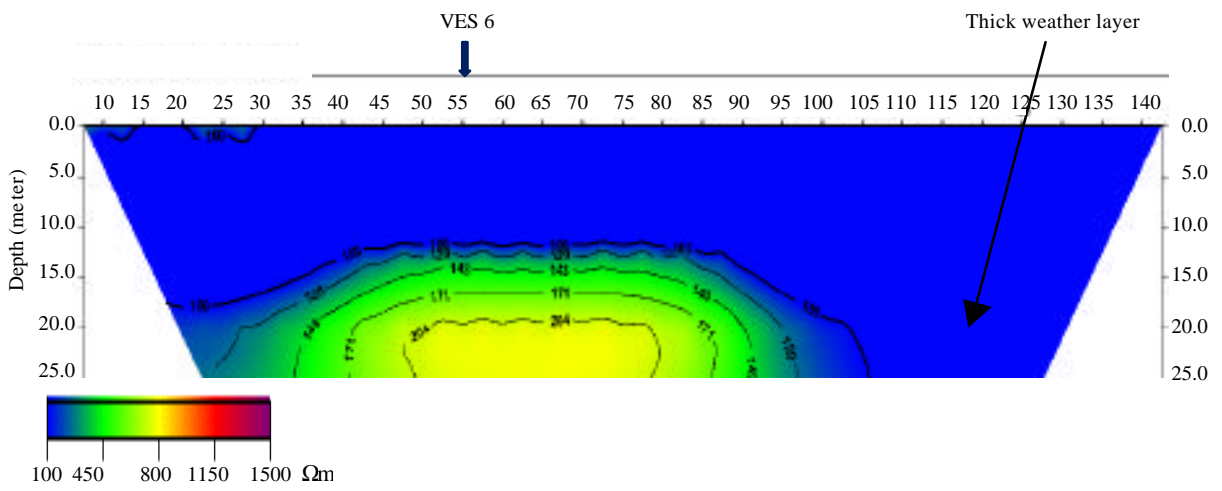

Fig. 20: 2-D Electrica; resistivity inverse model section for profile 8

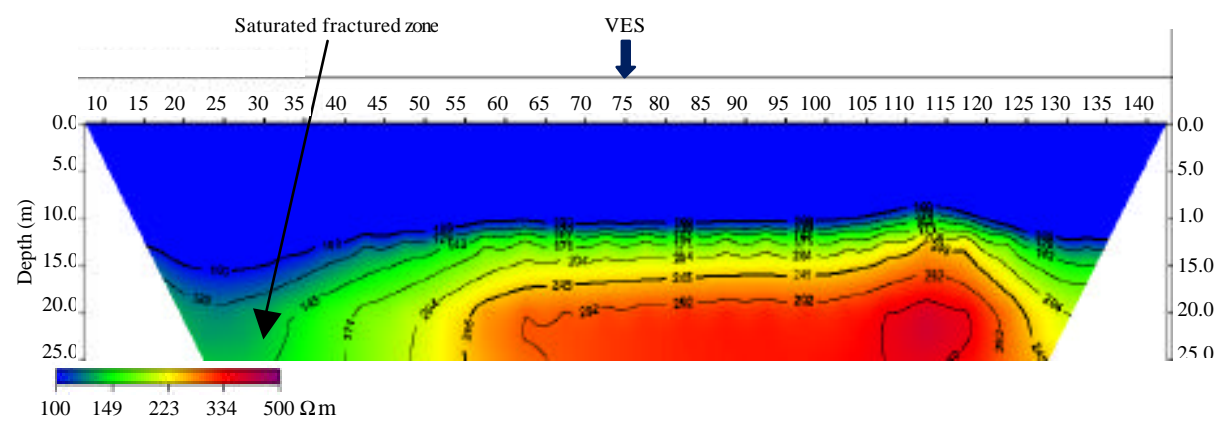

Fig. 21: 2-D Electrica; resistivity inverse model section for profile 9

Underlying this top layer is a moderate resistivity layer with resistivity value ranging from $350-800 \Omega \mathrm{m}$ which was interpreted as the weathered layer with an average thickness of about $4 \mathrm{~m}$. The weathered layer is not thick and has uneven top and base along the profile. The base of the profile was occupied by fresh basement rock which has resistivity value greater than $1000 \Omega \mathrm{m}$. As observed from the 2-D inverted study, the weathering profile was not thick along the profile which means the basement was close to the surface thereby making it impossible for the 


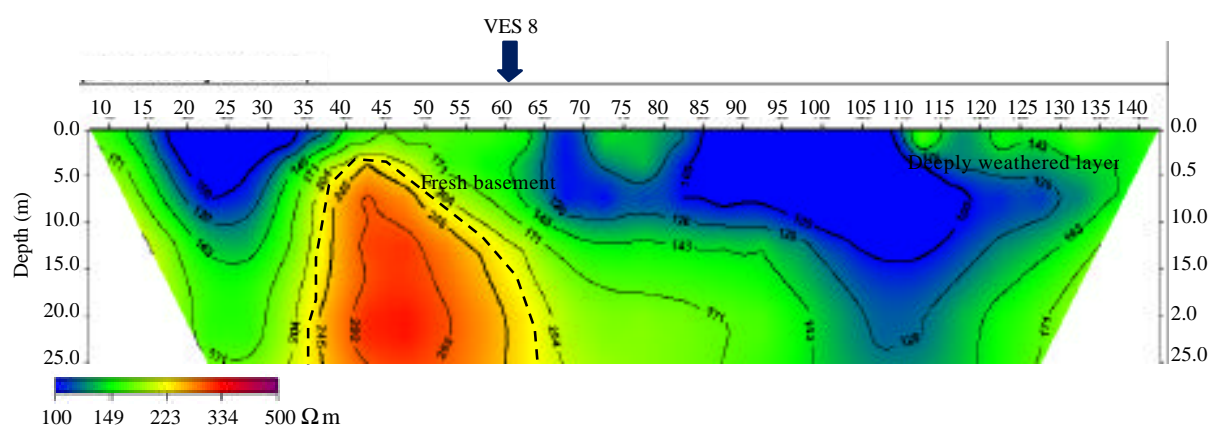

Fig. 22: 2-D Electrica; resistivity inverse model section for profile 10

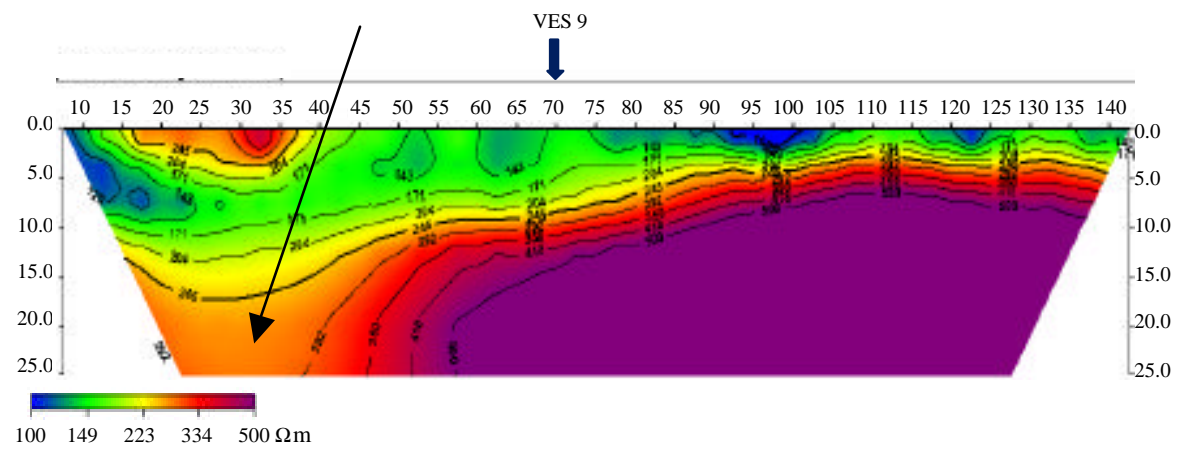

Fig. 23: 2-D Electrica; resistivity inverse model section for profile 11

weathered layer to accumulate water that can be enough for abstraction through hand dug well or tube well. The basement has uneven surface which is as a result of irregular weathering on the basement. The basement structure along this profile does not give room for groundwater accumulation because there was no evidence of fractured or saturated zones on it. At $120 \mathrm{~m}$ on the profile line, VES 3 (Fig. 6) was carried out to corroborate the 2-D ERT at that point. The VES revealed three geoelectric layers which correlate with what was obtained on the ERT section. The subsurface layer inferred from the VES are the topsoil, weathered layer and the fresh basement with resistivities 396,53 and $6958 \Omega \mathrm{m}$ respectively. The topsoil is $0.8 \mathrm{~m}$ thick and the weathered layer is about $3.8 \mathrm{~m}$ thick which reflects that the overburden here is thin which corroborate what was obtained across the profile line. The VES revealed that the overburden lies directly on the fresh basement and the contact between them do not show any evidence of fracturing.

Profile 6: The 2-D electrical resistivity imaging along profile 6 (Fig. 18) reflects the subsurface resistivity within the study area. This profile was occupied along Northwest-Southeast direction and is $150 \mathrm{~m}$ long. In this profile the upper part revealed relatively low resistive materials as the top layer which has resistivity values ranging between 100-250 $\Omega \mathrm{m}$ with average thickness of about $5.0 \mathrm{~m}$. This top layer was interpreted as reworked topsoil that is clayey in nature. Underlying the top layer is a moderately resistive material with resistivity value ranging from $300-700 \Omega \mathrm{m}$ and was interpreted as weathered basement which is made up of graveling clayey-sand that weathers from the basement rock. The base of this layer is uneven and this is as a result of uneven weathering that has affected the area under investigation. Also noted on the profile is that the weathered basement is not thick enough to accumulate groundwater as suggested by Olayinka et al. (1997). Below this layer is occupied by the last layer mapped by the 2-D imaging which is characterized by high resistivity value of above $1000 \Omega \mathrm{m}$ and was interpreted as fresh basement. As observed on the 2-D section, the contact between the weathered and fresh basement is either fractured or saturated. Also noted is that the beginning of the profile line, i.e., from 0-20 $\mathrm{m}$ and also from $115-125 \mathrm{~m}$ show signature on the section that can be interpreted as fractured zone or deep weathering profile which can serve as water collecting centre. VES 4 (Fig. 7) was carried out at $90 \mathrm{~m}$ on the profile line and it revealed the geoelectric 
layer with resistivity value $396 \Omega \mathrm{m}$ for the topsoil with thickness of about $1.8 \mathrm{~m}, 137 \Omega \mathrm{m}$ for the weathered layer with thickness of about $3.8 \mathrm{~m}$ and $3231 \Omega \mathrm{m}$ for the fresh basement. The overburden at this point is not thick both on the 2-D ERT and on the VES which gave credence to the early assertion that the chemical weathering that occur here are not deep.

Profile 7: The inverted section of 2-Dimensional imaging of profile 7 with total spread length of about $100 \mathrm{~m}$ is shown in Fig. 19. The profile was obtained in West-East and is located around the central part of the study area. The upper part of the section revealed materials with resistivity values ranging between $<100-250 \Omega$ m which extends from the surface to an average depth of about $6 \mathrm{~m}$. This layer was interpreted as topsoil and it is composed of reworked clayey soil which was responsible for the low resistivity values obtained for it. Underlying this layer is a moderately resistive layer with resistivity ranging from $300-800 \Omega \mathrm{m}$ which was interpreted as weathered basement and was made of clayey-sand with gravelling sand embedded within it. This layer occupied virtually the whole section except where there are intrusions of fresh basement. The last layer here has resistivity values greater than $1000 \Omega \mathrm{m}$ and was interpreted as fresh basement. This layer intrudes the weathered layer at the beginning of the profile and also between 55 and $70 \mathrm{~m}$. The depression between the intruded basements was interpreted as fractured zone which can serve as groundwater storage centre for water dispersed at the crest of the intruded basements. On this profile, VES 5 (Fig. 8) was carried out at $55 \mathrm{~m}$ and the geoelectric parameters obtained from the VES revealed three geoelectric layers which were interpreted as topsoil, weathered layer and fresh basement.

Profile 8: Figure 20 shows the subsurface resistivity as displayed by $2-D$ electrical resistivity imaging along profile 8 with spread length of $150 \mathrm{~m}$ and obtained in West-East direction. The upper part of the inverted section reveals a low resistivity layer which covers more than $70 \%$ of the entire section. The resistivity value of this layer ranging between $<100-120 \Omega \mathrm{m}$ and was interpreted as topsoil/weathered basement. The topsoil and the weathered basement here have close resistivity signature because the degree of weathering here is intense and that is why they are assumed to be same layer. The weathering profile here is thick enough to accommodate groundwater as suggested by Olayinka et al. (1997). The intruding layer into the weathered basement has resistivity greater than $150 \Omega \mathrm{m}$ and this was considered fairly low basement resistivity which is suggestive of the presence of fractures within the basement and it could consequently house groundwater (Olayinka and Olorunfemi, 1992). The 2-D ERI show that the in-situ chemical weathering that occurs around the area is deep and this result in thick overburden across the ERT section. Basement rock was not observed on the 2-D ERT section from $90 \mathrm{~m}$ to the end which is also another evidence of deep weathering around the area. The overburden here is thick enough to store groundwater. VES 6 (Fig. 9) was obtained at $55 \mathrm{~m}$ on this profile revealed three geoelectric layers which are the topsoil, the weathered layer (Clayey) and the fractured unit. The topsoil has resistivity of $79 \Omega \mathrm{m}$ with thickness of about $2.2 \mathrm{~m}$, the weathered layer has resistivity of $66 \Omega \mathrm{m}$ with thickness of about $4.8 \mathrm{~m}$ and the fractured basement which has resistivity of $257 \Omega \mathrm{m}$.

Profile 9: Profile 9 (Fig. 21) is displayed as 2-D electrical resistivity imaging which reflects the subsurface resistivity within the study area. This profile was obtained at the Southern part of the study area and is occupied along Northwest-Southeast direction with spread of $150 \mathrm{~m}$. The top of the profile is occupied by relatively low resistive materials as the top layer which has resistivity value of between $<100-140 \Omega \mathrm{m}$ with thickness average thickness of about $10 \mathrm{~m}$. This top layer was interpreted as reworked topsoil which composed clayey soil. The thick top layer revealed the intensity of weathering around the area occupied by the profile line. The top layer is underlain by moderately resistive materials with resistivity value ranging from 150-240 $\Omega \mathrm{m}$ with average thickness of about $6 \mathrm{~m}$ and was interpreted as weathered basement which is made up of graveling clayey-sand. The base of this layer is uneven and this was as a result of uneven insitu chemical weathering that has affected the area under investigation. Also noted on the profile is that the weathered basement may not be thick enough to accumulate groundwater as suggested by Olayinka et al. (1997). However, observed at the beginning of the profile is a very thick weathering profile in which the last layer assumed to be bedrock was absent. The moderate resistivity observed at this area on the profile according to Olayinka and Olorunfemi (1992) is suggestive of fractured zone and is saturated. Below this layer is occupied by the last layer mapped by the 2-D imaging which is characterized by high resistivity value of above $300 \Omega \mathrm{m}$ and was interpreted as fractured unit. As observed on the 2-D section, the basement and weathered layer contact is fractured and which is responsible for the decrease in the resistivity value of the basement around the profile line. Observed on the VES 6 (Fig. 10) obtained at $75 \mathrm{~m}$ on the profile is that the topsoil and the weathered 
basement were combined to form a single layer which is interpreted as topsoil. The base of the geoelectric layer obtained from the VES is occupied by fractured unit which is evident on the 2-D ERT section.

Profile 10: The 2-D resistivity imaging for profile 10 is displayed as section in Fig. 22 . The profile is $150 \mathrm{~m}$ long and is located in the eastern part of the study area. The profile is obtained in North-South direction. The upper part of the profile is made of varying degree of resistivity value which shows the complexity in geology of the area. The topsoil has resistivity ranging from $<100-150 \Omega \mathrm{m}$ and has varying thickness across the area. The topsoil is made of reworked clayey soil around the area. This layer is followed by a moderate resistive layer. The resistivity of this layer ranges between 150-240 $\Omega \mathrm{m}$ and has varying thickness across the profile. The top and base of this layer is uneven because of the grade of weathering across the area. This moderate resistive layer was interpreted as weathered layer which occupied about $50 \%$ of the entire section. The high resistivity layer that occurs as an intrusion within the 2-D section was interpreted as the basement rock. The unevenness observed on the section is as a result of differential weathering that has occurred along the profile line. The low resistive layer observed to occur at the base of the section is as a result of deep in-situ chemical weathering and also this zone will serve as groundwater collecting centre. At $60 \mathrm{~m}$ on the profile VES 7 (Fig. 11) was carried out to correlate the ERT result. Three layer were observed from the geolectric parameters which was interpreted as topsoil with resistivity of $91 \Omega \mathrm{m}$ and thickness of about $2 \mathrm{~m}$, weathered layer with resistivity of 35 and thickness of about $11.5 \mathrm{~m}$ and the basement with resistivity of $301 \Omega \mathrm{m}$.

Profile 11: Profile 11 (Fig. 23) is displayed as 2-D electrical resistivity imaging which reflects the subsurface resistivity within the study area. This profile which is $150 \mathrm{~m}$ long was obtained at the eastern part of the study area and is occupied along West-East direction. The top of the profile was occupied by mixture of relatively low and high resistive materials as the top layer which has resistivity value of between $<100-350 \Omega \mathrm{m}$ with average thickness of about $2 \mathrm{~m}$. The relatively low resistive part of the layer was interpreted as reworked topsoil which composed clayey soil while relatively high resistive portion of layer was interpreted as compacted lateritic soil. The top layer is underlain by moderately resistive materials with resistivity value ranging from $150-240 \Omega \mathrm{m}$ with average thickness of about $5 \mathrm{~m}$ and was interpreted as weathered layer which is made up of graveling clayey-sand. The top and the base of this layer are uneven and this is as a result of differential weathering that has affected the area under investigation. Also noted on the profile was that the weathered layer may not be thick enough to accumulate groundwater as suggested by Olayinka et al. (1997). However, observed at the beginning of the profile is a portion that has moderate resistivity where the last layer assumed to be bedrock was absent. The resistivity signature observed at this portion of the profile is indicative of fractured zone. The moderate resistivity observed at the other part of the profile which represent weathered zone is not thick enough to accommodate groundwater as suggested by Olayinka and Olorunfemi (1992). Below this layer is occupied by the last layer mapped by the 2-D ERT which is characterized by high resistivity value of above $300 \Omega \mathrm{m}$ and was interpreted as fresh basement. As observed on the 2-D section, the contact between the weathered and fresh basement is either fractured or wet which is responsible for the decrease in the resistivity value of the basement around the profile line. VES 9 (Fig. 12) was carried out on the profile at $70 \mathrm{~m}$ and from the geoelectric parameters obtained from it, three subsurface layers were delineated. The layers were interpreted based on the resistivity value observed and the layers are, the topsoil, weathered layer and the fresh basement.

This study focuses on effort to advancing the understanding of groundwater occurrence in Gbongudu community. A combination of 1-D and 2-D electrical resistivity data were carried out and analyzed to identify the influence of geological structures on groundwater occurrence within the study area. Kumar (2012), suggested that the depth to basement rock and the topography of the bedrock are factors that are very important in groundwater prospecting. Louis et al. (2002) suggested that the geological structures often obtained in basement terrain are characterized presence of fresh basement overlain by varying thickness of the weathered overburden. In a typical basement terrain, the geoelectric layer sequence that is most common consists of top layer, highly weathered layer which is most likely clay/clayey sand, fractured/fresh basement (Olayinka et al., 1997). Information on the horizontal and vertical variation in formations, weathered layer thickness, resistivity of the weathered layer, occurrence of fractured zones, basement rock resistivity are obtained from the interpretation of data acquired, processed and interpreted from 2-D electrical resistivity tomography and vertical electrical soundings. From the inverted sections for the 2-D resistivity imaging and the VES result, the three major layers have been identified base on the resistivity of each layers and interpreted layers are the topsoil which consist of reworked clayey soil and compacted lateritic clay in some 
area, the weathered basement consist of sandy-clayey or clayey sand that impregnated with gravelling sand and the fresh/fractured basement.

In general, the distribution of the subsurface resistivity in the inverted models obtained (Fig. 13-23) is seen as wide dissimilarity in the resistivity of the soil at different depth along the profiles. The large variation of resistivity observed on the $2-\mathrm{D}$ sections shown that the formations in the study area are inhomogeneous. As observed in all the inverted models, the top layer is characterized by its relatively low resistivity value across the study area except in profile 11 where some portion of the top layer has relatively high resistivity. The top layer resistivity and thickness across the study area ranging from $<100-350 \Omega \mathrm{m}$ and 2-10 $\mathrm{m}$ thick. The top layer is thicker in profiles 2, 8,9 and 10 which is located at the edges of the study area while the rest profiles that are found within the center part have lesser thickness of top layer. The heterogeneity observed with the top layer is due to presence of clayey soil, reworked clayey soil, compacted lateritic soil and sometimes exposed basement rock. The middle layer which is characterized by moderate resistivity is interpreted as weathered layer. The resistivity of this layer ranges from $150-800 \Omega \mathrm{m}$ and its thickness varies from $3-11 \mathrm{~m}$. This layer is considered to be dominated by gravelling sandy clay or clayey sand. Hydro-geologically, this layer is significant because the material constituents of it is characterized by high porosity and contains significant amount of water but the permeability is low due to relatively high clay content (Baker, 2001). In this study, this layer serves as the main groundwater aquifer as revealed in Fig. 14, 19, 20, 21 and 22.

Underlying the weathered basement (the unconfined aquferous zone) is the fracture unit and fresh basement with resistivity greater than $350 \Omega \mathrm{m}$. The top of the basement with resistivity ranges between $350-800 \Omega \mathrm{m}$ is regarded as fractured which in some places is saturated or moistened while the lower section with resistivity above $1000 \Omega \mathrm{m}$ is considered as fresh basement (Olayinka et al., 1997). The fractured basement in the study area is not too thick with average thickness of about $4 \mathrm{~m}$ and serves as unconfined aquiferous zone where saturated (Olorunfemi and Fasuyi, 1993). The VES carried out were to corroborate the ERT results which in some places correlate with the ERT. The VES were delineated into topsoil, weathered layer and basement (Fractured or fresh basement) from the geoelectric parameters obtained. The difference mineralogy and structures associated with the bedrock within the area investigated is the cause why there is variation in the bedrock resistivity (Oladapo et al., 2004). Across the area investigated, the overburden thickness varies with some area having lesser thickness while it is very thick in few places. Olorunfemi and Okhue, (1992), Oladapo et al. (2004), Oyedele and Olayinka, (2012), have identified that the area with thick overburden in southwestern Nigeria basement complex has zones of high groundwater potentials through geophysical studies. Moreso, Olayinka et al. (2004) and Olorunfemi and Fasuyi, (1993) classified the moderately weathered and fractured basements in the basement complex of Nigeria with resistivity ranging between $100-800 \Omega \mathrm{m}$ as good groundwater potential. The ridges and furrows pattern observed between the intermediate weathered layer and basement rock (Fig. 13, 16, 18, 19, 21, 22 and 23) show differential weathering and fracturing associated with gneissic rocks which typifies areas of hydro-geological potential zones for groundwater accumulation and target for groundwater development. The groundwater accumulation is favoured by zones with intense basement fracturing and extensive or local thickening of overburden material.

Layer and the fresh basement which could either be fractured or fresh. The upper part of the 2-D inverted model revealed material with resistivity between 100-250 $\Omega \mathrm{m}$ and an average thickness of $4 \mathrm{~m}$ which form the topsoil. The layer can be interpreted from the resistivity as lateritic clay where the resistivity value is high and clayey sand where the resistivity is not too high. The top layer is underlain by a more resistive layer with average thickness of about $7 \mathrm{~m}$ and has resistivity value ranges from $250-700$ $\Omega \mathrm{m}$. This layer covered the entire profile line but with varying thickness and is found at different depth because of varying degree of weathering profile. The weathered and fresh basement contact is suspected to be either fractured or saturated because it has resistivity lower than that of the fresh basement. The depression found between 65 and $90 \mathrm{~m}$ on the profile which has resistivity value ranges 722 and $1033 \Omega \mathrm{m}$ which is less than that of the fresh basement is interpreted as fractured zone and could be saturated. The base of the profile is occupied by fresh basement with resistivity value greater than $1000 \Omega \mathrm{m}$. The intruding fresh basement found at the base of the profile show uneven surface of the basement which is as a result of the variation in the degree of resistance to chemical weathering by the underlying rocks along the profile at the subsurface. On this profile, a VES Fig. 4 was carried out at $70 \mathrm{~m}$ and three geoelectric layers was revealed which were interpreted base on geoelectric parameters observed as topsoil weathered layer and fractured unit. This correspond to what is observed on the 2D ERT inverted model section at $70 \mathrm{~m}$. The VES was used as a complementary tool to the ERT result. 
Profile 2: Figure 14 was obtained in NE-SW direction and located in the northeastern part of the study area with a length of $120 \mathrm{~m}$. The variation in the resistivity values as seen on the profile is an indicative of anomalous zones. The upper part of the profile which is about $10 \mathrm{~m}$ thick is occupied by a low resistivity layer which has resistivity value ranging between $100-130 \Omega \mathrm{m}$. This layer is interpreted to be wet sandy-clay and is not too compacted which is responsible for the low resistivity. The top layer is underlying by a layer with resistivity value ranging between 140-250 $\Omega \mathrm{m}$ with average thickness of about $7 \mathrm{~m}$. This layer is interpreted as weathered layer which is composed of clayey-sand. Below this layer is the last layer which has resistivity value higher than $250 \Omega \mathrm{m}$. This layer is interpreted as fractured basement and is likely be saturated which is responsible for the low resistivity. The layers displayed have almost equal thickness along the profile which indicates uniform weathering along the profile line.

Profile 3: Image of the 2-D electrical resistivity imaging for profile 3 is shown in Fig. 15. The profile is located in the central part of the study area and is obtained in Northeast-Southwest direction with total length of $100 \mathrm{~m}$ due to space constraint. The inverted section delineate three layers which are the topsoil weathered layer and fresh bedrock. The topsoil has resistivity value ranges from 100-150 $\Omega \mathrm{m}$ with average thickness of about $2 \mathrm{~m}$ which is interpreted to compose of loose but wet soil particles which is responsible for the low resistivity observed on the section. This is underlain by a layer which has resistivity ranges from 200-600 $\Omega \mathrm{m}$ which has average thickness of about $3 \mathrm{~m}$. The layer is interpreted to be weathered layer that composed of clayey soil impregnated with gravelling sand. The base of this profile is occupied by fresh basement rock which has resistivity $<1000 \Omega \mathrm{m}$. The contact between the weathered layer and fresh basement may either be fractured or saturated. The uneven surface of the basement rock is as a result varying degree of resistant to weathering by the basement rock.

Profile 4: Figure 16 shows the subsurface resistivity as displayed by 2-D electrical resistivity imaging along profile 4 with a total spread length $200 \mathrm{~m}$. The profile was obtained in Northeast-Southwest direction and is located at the central part of the study area. At near surface with average thickness of about $3 \mathrm{~m}$ and is occupied by the top layer with low resistivity values of between 100-250 $\Omega \mathrm{m}$ which is interpreted as topsoil that is made of reworked soil. This topsoil is getting thicker towards the end of the profile which shows evidence of deeper weathering profile along the section. A moderate resistivity layer which has resistivity value ranges between $300-700 \Omega \mathrm{m}$ with an average thickness of about $4 \mathrm{~m}$. This layer is interpreted as the weathered layer and composed mainly clayey sandwhich has gravel of quartz embedded within it. The weathered layer has uniform thickness across the profile but is encountered at different depth. Occupying the base of the profile is a very high resistivity layer with resistivity of above $1100 \Omega \mathrm{m}$ and is interpreted as fresh basement. The fresh basement is close to the surface from the beginning of the profile to about $170 \mathrm{~m}$ and this shows that the weathering profile is not thick which sometimes make it impossible for the weathered layer to be saturated. The basement has uneven surface which result from the irregular weathering on the basement. The uneven surface of the basement made it difficult for groundwater to accumulate within the weathered basement because it is not thick enough. The depression found at the end of the profile where the fresh basement is not too evident could be as result of fracture within the basement and if fracture, it will serve as groundwater storage center for water that infiltrates from $80 \mathrm{~m}$ on the profile. The VES (Fig. 5) carried out at $53 \mathrm{~m}$ shows topsoil and fresh basement. The topsoil which composed of clayey soil has thickness of about $2.4 \mathrm{~m}$ with resistivity of $82 \Omega \mathrm{m}$. The VES result show evidence of fracturing at the top of the fresh basement and the regolith here is thin.

Profile 5: Figure 17 shows the subsurface resistivity as displayed by 2-D electrical resistivity imaging along profile 5 with spread length $150 \mathrm{~m}$ and obtained in northwest-southeast direction. Observed at the topmost of the profile is very low resistivity value ranges from $<100-300 \Omega \mathrm{m}$ with average thickness of about $4 \mathrm{~m}$. This topmost layer which has uneven base due to different degree of weathering across the profile is interpreted as topsoil that is made of clayey soil. Underlain this top layer is a moderate resistivity layer with resistivity value ranges from $350-800 \Omega \mathrm{m}$ which is interpreted as the weathered layer with an average thickness of about $4 \mathrm{~m}$. The weathered layer is not thick and has uneven top and base along the profile. The base of the profile is occupied by fresh basement rock which has resistivity value $>1000 \Omega \mathrm{m}$. Evident from the $2-\mathrm{D}$ inverted section is that the weathering profile is not thick along the profile which means the basement is close to the surface thereby making it impossible for the weathered layer to accumulate water that can be enough for abstraction through hand dug well or tube well. The basement has uneven surface which is as a result of irregular weathering on the basement. The basement structure along this profile does not give room for groundwater accumulation because there is no evidence 
of fractured or saturated zones on it. At $120 \mathrm{~m}$ on the profile line, a VES Fig. 6 was carried out to corroborate the 2-D ERT at that point. The VES revealed three subsurface layer which correlate with what is obtainable on the ERT section. The subsurface layer inferred from the VES are the topsoil, weathered layer and the fresh basement with resistivity 396,53 and $6958 \Omega \mathrm{m}$, respectively. The topsoil is $0.8 \mathrm{~m}$ thick and the weathered layer is about $3.8 \mathrm{~m}$ thick which reflects that the overburden here is thin and is a testament to what is obtained across the profile line. The VES revealed that the overburden lies directly on the fresh basement and the contact between them do not show any evidence of fracturing.

Profile 6: The 2-D electrical resistivity imaging along profile 6 Fig. 18 reflects the subsurface resistivity within the study area. This profile was occupied along northwest-southeast direction and is $150 \mathrm{~m}$ long. In this profile the upper part revealed relatively low resistive materials as the top layer which has resistivity value of between $<100-250 \Omega \mathrm{m}$ with average thickness of about $5.0 \mathrm{~m}$. This top layer is interpreted as reworked topsoil that is clayey in nature. Underlain the top layer is a moderately resistive materials with resistivity value ranging from $300-700 \Omega \mathrm{m}$ and is interpreted as weathered basement which is made up of graveling clayey-sand that weathers from the basement rock. The base of this layer is uneven and this is as a result of uneven weathering that has affected the area under investigation. Also, noted on the profile is that the weathered basement is not thick enough to accumulate groundwater as suggested by Olayinka et al. (1997). Below this layer is occupied by the last layer mapped by the 2-D imaging which is characterized by high resistivity value of above $1000 \Omega \mathrm{m}$ and is interpreted as fresh basement. As observed on the 2-D section, the contact between the weathered and fresh basement is either fractured or saturated. Also, noted is that the beginning of the profile line, i.e., from $0-20 \mathrm{~m}$ and also from $115-125 \mathrm{~m}$ show signature on the section that can be interpreted as fractured zone or deep weathering profile which can serve as water collecting centre. A VES (Fig. 7) was carried out at $90 \mathrm{~m}$ on the profile line and it revealed the geoelectric layer with resistivity value 396 $\Omega \mathrm{m}$ for the topsoil with thickness of about $1.8 \mathrm{~m}, 137 \Omega \mathrm{m}$ for the weathered layer with thickness of about $3.8 \mathrm{~m}$ and $3231 \Omega \mathrm{m}$ for the fresh basement. The overburden at this point is not thick both on the 2-D ERT and on the VES which give credence to the early assertion that the chemical weathering that occur here are not deep.

Profile 7: The inverted section of 2-Dimensional imaging of profile 7 with total spread length of about $100 \mathrm{~m}$ is shown in Fig. 19. The profile was obtained in west-east and is located around the central part of the study area. The upper part of the section revealed materials with resistivity values ranging between $<100-250 \Omega \mathrm{m}$ which extends from the surface to an average depth of about 6 $\mathrm{m}$. This layer is interpreted as topsoil and it is composed of reworked clayey soil which is responsible for the low resistivity value obtained for it. Underlain this layer is a moderately resistive ayer with resistivity ranging from $300-800 \Omega \mathrm{m}$ which is interpreted as weathered basement and is made of clayey-sand with gravelling sand embedded within it. This layer occupied virtually the whole section except where there are intrusions of fresh basement. The last layer here has resistivity values $>1000 \Omega \mathrm{m}$. The layer is interpreted as fresh basement. This layer intrudes the weathered layer at the beginning of the profile and also between 55 and $70 \mathrm{~m}$. The depression between the intruded basements is interpreted as fractured zone which can serve as groundwater storage centre for water dispersed at the crest of the intruded basements. On this profile, a VES (Fig. 8) was carried out at $55 \mathrm{~m}$ and the geoelectric parameters obtained from the VES revealed three geoelectric layer which is interpreted as topsoil, weathered layer and fresh basement.

Profile 8: Figure 20 shows the subsurface resistivity as displayed by 2-D electrical resistivity imaging along profile 8 with spread length $150 \mathrm{~m}$ and obtained in West-East direction. The upper part of the inverted section reveal a low resistivity layer which covers more than $70 \%$ of the entire section. The resistivity value of this layer ranges between $<100-120 \Omega \mathrm{m}$ and is interpreted as topsoil/weathered basement. The topsoil and the weathered basement here have close resistivity signature because the degree of weathering here is intense and that is why they are assuming to be same layer. The weathering profile here is thick enough to accommodate groundwater as suggested by Olayinka et al. (1997). The intruding layer into the weathered basement has resistivity $>150 \Omega \mathrm{m}$ and this is considered fairly low basement resistivity which is suggestive of the presence of fractures within the basement and it could consequently house groundwater (Olorunfemi and Okhue, 1992). The 2-D ERT show that the in-situ chemical weathering that occur around the area is deep and this result in thick overburden across the ERT section. Basement rock was not observed on the 2-D ERT section from $90 \mathrm{~m}$ to the end which is also another evidence of deep weathering around the area. The overburden here is thick enough to store groundwater. A VES (Fig. 9) was obtained at $55 \mathrm{~m}$ on this profile revealed three geoelectric 
layer which are the topsoil, the weathered layer (Clayey) and the fractured unit. The topsoil has resistivity of 79 $\Omega \mathrm{m}$ with thickness of about $2.2 \mathrm{~m}$, the weathered layer has resistivity of $66 \Omega \mathrm{m}$ with thickness of about $4.8 \mathrm{~m}$ and the fractured basement which has resistivity of $257 \Omega \mathrm{m}$.

Profile 9: Profile 9 (Fig. 21) is displayed as 2-D electrical resistivity imaging which reflects the subsurface resistivity within the study area. This profile was obtained at the Southern part of the study area and is occupied along Northwest Southeast direction and is $150 \mathrm{~m}$ long. The top of the profile is occupied by relatively low resistive materials as the top layer which has resistivity value of between $<100-140 \Omega \mathrm{m}$ with thickness average thickness of about $10 \mathrm{~m}$. This top layer is interpreted as reworked topsoil which composed clayey soil. The thick top layer revealed the intensity of weathering around the area occupied by the profile line. The top layer is underlain by moderately resistive materials with resistivity value ranging from 150-240 $\Omega \mathrm{m}$ with average thickness of about $6 \mathrm{~m}$ and is interpreted as weathered basement which is made up of graveling clayey-sand. The base of this layer is uneven and this is as a result of uneven insitu chemical weathering that has affected the area under investigation. Also, noted on the profile is that the weathered basement may not be thick enough to accumulate groundwater as suggested by Olayinka et al. (1997). However, observed at the beginning of the profile is a very thick weathering profile where the last layer assumed to be bedrock is absent. The moderate resistivity observed at this area on the profile according to Olayinka and Olorunfemi (1992) is suggestive of fractured zone and is saturated. Below this layer is occupied by the last layer mapped by the 2-D imaging which is characterized by high resistivity value of above $300 \Omega \mathrm{m}$ and is interpreted as fractured unit. As observed on the 2-D section, the basement and weathered layer contact is fractured and which is responsible for the decrease in the resistivity value of the basement around the profile line. Observed on the VES (Fig. 10) obtained at $75 \mathrm{~m}$ on the profile is that the topsoil and the weathered basement were combined to form a single layer which is interpreted as topsoil. The base of the geoelectric layer obtained from the VES is occupied by fractured unit which is evident on the 2-D ERT section.

Profile 10: The 2-D resistivity imaging for profile 10 is displayed as section in Fig. 22. The profile is $150 \mathrm{~m}$ long and is located in the eastern part of the study area. The profile is obtained in North-South direction. The upper part of the profile is made of varying degree of resistivity value which shows the complexity in geology of the area. The topsoil has resistivity ranges from $<100-150 \Omega \mathrm{m}$ and has varying thickness across the area. The topsoil is made of reworked clayey soil around the area. This layer is followed by a moderate resistive layer. The resistivity of this layer ranges between 150-240 $\Omega \mathrm{m}$ and has varying thickness across the profile. The top and base of this layer is uneven because of the grade of weathering across the area. This moderate resistive layer is interpreted as weathered layer which occupied about $50 \%$ of the entire section. The high resistivity layer that occur as an intrusion within the 2-D section is interpreted as the basement rock. The unevenness observed on the section is as a result of differential weathering that has occurred along the profile line. The low resistive layer observed to occur at the base of the section is as a result of deep in-situ chemical weathering and also this zone will serve as groundwater collecting centre. At $60 \mathrm{~m}$ on the profile a VES (Fig. 11) was carried out to correlate the ERT result. Three layer were observed from the geolectric parameters which is interpreted as topsoil with resistivity of $91 \Omega \mathrm{m}$ and thickness of about $2 \mathrm{~m}$, weathered layer with resistivity of 35 and thickness of about $11.5 \mathrm{~m}$ and the basement with resistivity of $301 \Omega \mathrm{m}$.

Profile 11: Profile 11 (Fig. 23) is displayed as 2-D electrical resistivity imaging which reflects the subsurface resistivity within the study area. This profile which is 150 $\mathrm{m}$ long was obtained at the eastern part of the study area and is occupied along west-east direction. The top of the profile is occupied by mixture of relatively low and high resistive materials as the top layer which has resistivity value of between $<100-350 \Omega \mathrm{m}$ with average thickness of about $2 \mathrm{~m}$. The relatively low resistive part of the layer is interpreted as reworked topsoil which composed clayey soil while relatively high resistive portion of layer is interpreted as compacted lateritic soil. The top layer is underlain by moderately resistive materials with resistivity value ranging from 150-240 $\Omega \mathrm{m}$ with average thickness of about $5 \mathrm{~m}$ and is interpreted as weathered layer which is made up of graveling clayey-sand. The top and the base of this layer is uneven and this is as a result of differential weathering that has affected the area under investigation. Also, noted on the profile is that the weathered layer may not be thick enough to accumulate groundwater as suggested by Olayinka et al. (1997). However, observed at the beginning of the profile is a portion that has moderate resistivity where the last layer assumed to be bedrock is absent. The resistivity signature observed at this portion of the profile is indicative of fractured zone. The moderate resistivity observed at the other part of the profile which represent weathered zone 
is not thick enough to accommodate groundwater as suggested by Olorunfemi and Okhue (1992). Below this layer is occupied by the last layer mapped by the 2-D ERT which is characterized by high resistivity value of above $300 \Omega \mathrm{m}$ and is interpreted as fresh basement. As observed on the 2-D section, the contact between the weathered and fresh basement is either fractured or wet which is responsible for the decrease in the resistivity value of the basement around the profile line. A VES (Fig. 12) was carried out on the profile at $70 \mathrm{~m}$ and from the geoelectric parameters obtained from it, three subsurface layer were delineated. The layers were interpreted based on the resistivity value observed and the layers are the topsoil weathered layer and the fresh basement.

This study focuses on effort to advancing the understanding of groundwater occurrence in Gbongudu community. A combination of 1-D and 2-D electrical resistivity data were carried out and analyzed to identify the influence of geological structures on groundwater occurrence within the study area.

Kumar (2012) suggested that the depth to basement rock and the topography of the bedrock are factors that are very important in groundwater prospecting. Louis et al. (2002) suggested that the geological structures often obtained in basement terrain is characterized presence of fresh basement overlain by varying thickness of the weathered overburden. In a typical basement terrain, the geoelectric layer sequence that is most common consists of top layer, highly weathered layer which is most likely clay/clayey sand, fractured/fresh basement (Olayinka et al., 1997). Information on the horizontal and vertical variation in formations, weathered layer thickness, resistivity of the weathered layer, occurrence of fractured zones, basement rock resistivity are obtained from the interpretation of data acquired, processed and interpreted from 2-D electrical resistivity tomography and vertical electrical soundings. From the inverted sections for the 2-D resistivity imaging and the VES result, the three major layers have been identified base on the resistivity of each layers and interpreted layers are the topsoil which consist of reworked clayey soil and compacted lateritic clay in some area, the weathered basement consist of sandy-clayey or clayey sand that impregnated with gravelling sand and the fresh/fractured basement.

In general, the distribution of the subsurface resistivity in the inverted models obtained (Fig. 13-23) is seen as wide dissimilarity in the resistivity of the soil at different depth along the profiles. The large variation of resistivity observed on the $2-\mathrm{D}$ sections shown that the formations in the study area are inhomogeneous. As observed in all the inverted models, the top layer is characterized by its relatively low resistivity value across the study area except in profile 11 where some portion of the top layer has relatively high resistivity. The top layer resistivity and thickness across the study area ranges from $<100-350 \Omega \mathrm{m}$ and $2-10 \mathrm{~m}$ thick. The top layer is thicker in profiles $2,8,9$ and 10 which is located at the edges of the study area while the rest profile that are found within the center part have lesser thickness of top layer. The heterogeneity observed with the top layer is due to presence of clayey soil, reworked clayey soil, compacted lateritic soil and sometimes exposed basement rock. The middle layer which is characterized by moderate resistivity is interpreted as weathered layer. The resistivity of this layer ranges from $150-800 \Omega \mathrm{m}$ and its thickness varies from $3-11 \mathrm{~m}$. This layer is considered to be dominated by gravelling sandy clay or clayey sand. Hydro-geologically, this layer is significant because the material constituents of it is characterized by high porosity and contains significant amount of water but the permeability is low due to relatively high clay content (Baker, 2001). In this study, this layer serves as the main groundwater aquifer as revealed in Fig. 14 and 19-22.

Underlying the weathered basement (the unconfined aquferous zone) is the fracture unit and fresh basement with resistivity $<350 \Omega \mathrm{m}$. The top of the basement with resistivity ranges between $350-800 \Omega \mathrm{m}$ is regarded as fractured which in some places is saturated or moistened while the lower section with resistivity above $1000 \Omega \mathrm{m}$ is considered as fresh basement (Olayinka et al., 1997). The fractured basement in the study area is not too thick with average thickness of about $4 \mathrm{~m}$ and serves as unconfined aquiferous zone where saturated (Olorunfemi and Fasuyi, 1993). The VES carried out were to corroborate the ERT result which in some places correlate with the ERT. The VES were delineated into topsoil, weathered layer and basement (Fractured or fresh basement) from the geoelectric parameters obtained. The difference mineralogy and structures associated with the bedrock within the area investigated is the cause why there is variations in the bedrock resistivity (Oladapo et al., 2004). Across the area investigated, the overburden thickness varies with some area having lesser thickness while it is very thick in few places. Olorunfemi and Okhue (1992), Oladapo et al. (2004), Oyedele and Olayinka (2012) have identified that the area with thick overburden in southwestern Nigeria basement complex has zones of high groundwater potentials through geophysical studies. Moreso, Olayinka et al. (2004) and Olorunfemi and Fasuyis (1993) classified the moderately weathered and fractured basements in the basement complex of Nigeria with resistivity ranging between $100-800 \Omega \mathrm{m}$ as good groundwater potential. The ridges and furrows pattern 
observed between the intermediate weathered layer and basement rock (Fig. 13, 16, 18, 19, 21-23) show differential weathering and fracturing associated with gneissic rocks which typifies areas of hydro-geological potential zones for groundwater accumulation and target for groundwater development. The groundwater accumulation is favoured by zones with intense basement fracturing and extensive or local thickening of overburden material.

\section{CONCLUSIONS}

The influence of geology, weathering profiles and geological structures on groundwater potential, exploration and development in the study area were accessed using integrated 2-D electrical resistivity imaging and vertical electrical soundings. Three lithologic units were identified from the analyses of the inverted 2-D sections along the profiles and the VES. The lithologic units identified are top layer which is made of reworked clayey soil or compacted lateritic soil, weathered layer which contains gravelling sandy clayey or clayey sand that is impregnated with gravelling sand and the fractured/fresh basement. The overburden thickness varies from 3 to above $11 \mathrm{~m}$. The regolith or weathered basement unit in the study area serves as the water bearing units derived mostly from the in-situ weathered crystalline rocks. Areas identified as bedrock depressions and the fractured zones are groundwater collecting centres which are priority areas for groundwater development. Areas with relatively thick overburden and fractured basement are targets for groundwater exploration and development in the study area. Based on the results obtained from the study area, groundwater should be targeted towards the area (Profile 1-11) where the basement is fractured with relative thick overburden thickness. The VES helps to confirm the lithology delineated from the 2-D ERT.

\section{REFERENCES}

Al-Garni, M.A., 2009. Geophysical investigations for groundwater in a complex subsurface Terrain, Wadi Fatima, KSA: A case history. Jordan J. Civil Eng., 3: 118-136.

Barker, R.D., 2001. Imaging fractures in hard rock terrain. Master Thesis, University of Birmingham, Birmingham, England, UK.

Barker, R.D., C.C. White and J.F.T. Houston, 1992. Borehole Siting in an African Accelerated Draught Relief Project. In: The Hydrogeology of Crystalline Basement Aquifers in Africa, Wright, E.P. and W.G. Burgess (Eds.). Geological Society, London, UK., pp: 183-202.
Burger, H.R., 1992. Exploration Geophysics of the Shallow Subsurface. Prentice Hll, Englewood Cliffs, Pages: 489.

Crook, N., A. Binley, R. Knight, D.A. Robinson and J. Zarnetske et al., 2008. Electrical resistivity imaging of the architecture of substream sediments. Water Resour. Res., 44: 1-11.

Griffiths, D.H. and R.D. Barker, 1993. Two-dimensional resistivity imaging and modelling in areas of complex geology. J. Applied Geophys., 29: 211-226.

Hauck, C., D.V. Muhll and H. Maurer, 2003. Using DC resistivity tomography to detect and characterize mountain permafrost. Geophys. Prospect., 51: 273-284.

Hodlur, G.K., R. Dhakate and R. Andrade, 2006. Correlation of vertical electrical sounding and borehole-log data for delineation of saltwater and freshwater aquifers. Geophys., 71: G11-G20.

Hodlur, G.K., R. Dhakatea, T. Sirisha and D.B. Panaskar, 2010. Resolution of freshwater and saline water aquifers by composite geophysical data analysis methods. Hydrol. Sci. J., 55: 414-434.

Hsu, H.L., B.J. Yanites, C.C. Chen and Y.G. Chen, 2010. Bedrock detection using $2 \mathrm{D}$ electrical resistivity imaging along the Peikang River, central Taiwan. Geomorphol., 114: 406-414.

Hubbard, S.S. and Y. Rubin, 2006. Hydrogeological Characterization Using Geophysical Methods. In: The Handbook of Groundwater Engineering, Delleur, J. (Ed.). CRC Press, Boca Raton, Florida, pp: 1-52.

Kumar, D., 2012. Efficacy of electrical resistivity tomography technique in mapping shallow subsurface anomaly. J. Geol. Soc. India, 80: 304-307.

Loke, M.H., 2000. Electrical imaging surveys for environmental and engineering studies. A Practical Guide to 2D and 3D Surveys.

Loke, M.H., 2004. Tutorial: 2-D and3-D electrical imaging surveys. geotomo software, res2dinv 3.5 software. Geotomo Software, Penang, Malaysia.

Louis, I.F., F.I. Louis and A. Grambas, 2002. Exploring for favorable groundwater conditions in hardrock environments by resistivity imaging methods: Synthetic simulation approach and case study example. J. Electr. Electron. Eng., 14: 1-15.

NIMET., 2011. Nigerian metrological agency, daily weatherguide. Nigerian Meteorological Agency, Nigeria Television Authority, Abuja, Nigeria.

Oladapo, M.I., M.Z. Mohammed, O.O. Adeoye and O.O. Adetola, 2004. Geoelectric investigation of the Ondo-state housing corporation Estate, Ijapo, Akure, Southwestern Nigeria. J. Mining Geol., 40: 41-48. 
Olayinka, A.I., E.J. Akpan and O.A. Magbagbeola, 1997. Geoelectric sounding for estimating aquifer potential in the crystalline basement area around Shaki, Southwest Nigeria. Water Resour., 8: 71-81.

Olayinka, A.I., S.A. Amidu and M.A. Oladunioye, 2004. Use of electromagnetic profiling and resistivity sounding for groundwater exploration in the crystalline basement area of Igbeti, Southwestern Nigeria. Global J. Geol. Sci., 2: 243-253.

Olorunfemi, M.O. and E.T. Okhue, 1992. Hydrogeologic and geologic significance of a geoelectric survey in Ile Ife, Southwesten Nigeria. J. Min. Geol., 28: 221-229.

Olorunfemi, M.O. and S.A. Fasuyi, 1993. Aquifer types and the geoelectric/hydrogeologic characteristics of part of the central basement terrain of Nigeria (Niger state). J. Afr. Earth Sci. (Middle East), 16: 309-317.

Oyedele, E.A.A. and A.I. Olayinka, 2012. Statistical evaluation of groundwater potential of Ado-Ekiti, Southwest, Nigeria. Trans. J. Sci. Technol., 2: 110-127.

Oyinloye, A.O., 2011. Geology and Geotectonic Setting of the Basement Complex Rocks in South Western Nigeria: Implications on Provenance and Evolution. In: Earth and Environmental Sciences, Dar, I.A., (Ed.). InTech, Lahore, Pakistan, ISBN:9789533074689, pp: 98-117.

Pous, J., P. Queralt and R. Chavez, 1996. Lateral and topographic effects in geoelectric soundings. J. Appl. Geophys., 35: 237-248.
Rao, B.V., Y.S. Prasad and K.S. Reddy, 2013. Hydrogeophysical investigations in a typical Khondalitic terrain to delineate the kaolinised layer using resistivity imaging. J. Geol. Soc. India, 81: $521-530$.

Robinson, E.S. and C. Coruh, 1988. Basic Exploration Geophysics. Johnal Wiley and Sons, USA., Pages: 562.

Sharma, S.P. and V.C. Baranwal, 2005. Delineation of groundwater-bearing fracture zones in a hard rock area integrating very low frequency electromagnetic and resistivity data. J. Appl. Geophys., 57: 155-166.

Telford, W.M., L.P. Geldart and R.E. Sheriff, 1990. Applied Geophysics. 2nd Edn., Cambridge University Press, Cambridge, England, UK., Pages: 770.

Yang, C.H., P.H. Cheng, J.I. You and L.L. Tsai, 2002. Significant resistivity changes in the fault zone associated with the 1999 Chi-Chi earthquake, West-central Taiwan. Tectonophys., 350: 299-313.

Yi, M.J., J.H. Kim and S.H. Chung, 2003. Enhancing the resolving power of least-squares inversion with active constraint balancing. Geophys., 68: 931-941.

Zhou, Q.Y., H. Matsui and J. Shimada, 2004. Characterization of the unsaturated zone around a cavity in fractured rocks using electrical resistivity tomography. J. Hydraul. Res., 42: 25-31. 